FELIPE PESSOA DE MELO HERMIDA

\title{
CÉLULAS PROGENITORAS CD34+ DURANTE A AMPLIAÇÃO ESPLÊNICA NA MALÁRIA EXPERIMENTAL DE ROEDORES
}

Dissertação apresentada ao Programa de Pós-Graduação na Biologia da Relação Patógeno-Hospedeiro do Instituto de Ciências Biomédicas da Universidade de São Paulo, para obtenção do Título de Mestre em Ciências Biológicas. 
FELIPE PESSOA DE MELO HERMIDA

\section{CÉLULAS PROGENITORAS CD34+ DURANTE A AMPLIAÇÃO ESPLÊNICA NA MALÁRIA EXPERIMENTAL DE ROEDORES}

Dissertação apresentada ao Programa de Pós-Graduação na Biologia da Relação Patógeno-Hospedeiro do Instituto de Ciências Biomédicas da Universidade de São Paulo, para obtenção do Título de Mestre em Ciências Biológicas.

Área de concentração: Parasitologia

Orientador: Prof. Dr. Heitor Franco de Andrade Jr. 
DADOS DE CATALOGAÇÃO NA PUBLICAÇÃO (CIP)

Serviço de Biblioteca e Informação Biomédica do

Instituto de Ciências Biomédicas da Universidade de São Paulo

(C) reprodução total

Hermida, Felipe Pessoa de Melo.

Células progenitoras $\mathrm{CD} 34^{+}$durante a ampliação esplênica em malária experimental de roedores / Felipe Pessoa de Melo Hermida. -São Paulo, 2007.

Orientador: Heitor Franco de Andrade Júnior.

Dissertação (Mestrado) - Universidade de São Paulo. Instituto de Ciências Biomédicas. Departamento de Parasitologia. Área de concentração: Biologia da Relação Patógeno-Hospedeiro. Linha de pesquisa: Malária de roedores.

Versão do título para o inglês: CD34 ${ }^{+}$progenitor cells during spleen amplification in experimental rodent malaria.

Descritores: 1. Malária de roedores 2. Baço 3. Hematopoiese 4. CD34 5. Células tronco 6. Progenitoras hematopoiéticas I. de Andrade Júnior, Heitor Franco II. Universidade de São Paulo. Instituto de Ciências Biomédicas. Programa de Pós-Graduação em Biologia da Relação Patógeno-Hospedeiro III. Título. 
Candidato(a):

Título da Dissertação:

Orientador(a):
Felipe Pessoa de Melo Hermida.

Células progenitoras CD $34^{+}$durante a ampliação esplênica na malária experimental de roedores.

A Comissão Julgadora dos trabalhos de Defesa da Dissertação de Mestrado, em sessão pública realizada a

Heitor Franco de Andrade Júnior.
( ) Aprovado(a)
( ) Reprovado(a)

Examinador(a): Assinatura:

Nome:

Instituição:

Examinador(a): Assinatura:

Nome:

Instituição:

Presidente: Assinatura:

Nome:

Instituição: 


\section{Certificado}

Certificamos que o protocolo registrado sob $n^{\circ} \mathbf{0 2 4}$ nas fls. 30 do livro 2 para uso de animais em experimentação, sob a responsabilidade de Heitor Franco de Andrade Junior, Coordenador(a) da Linha de Pesquisa "Distribuição, quantificação e o efeito da suplementação de SDF-1 em células dendriticas CD34* e células CD11c* durante a esplenomegalia em malárias experimentais de roedores" do qual participou(aram) o(s) alunos Felipe Pessoa de Melo Hermida,, está de acordo com os Principios Éticos de Experimentação Animal adotado pelo Colégio Brasileiro de Experimentação Animal (COBEA) e foi aprovado pela COMISSÃO DE ÉTICA EM EXPERIMENTAÇÃO ANIMAL (CEEA) em 28.04.2006.

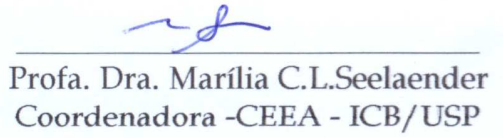

Profa. Dra. Marília C.L.Seelaender
Coordenadora -CEEA - ICB/USP
Ratichothlucer

Profa. Dra. Patrícia Castelucci Secretária Suplente CEEA - ICB/USP 


\section{Dedicatória}

Aos meus familiares e amigos pelo apoio e, principalmente, a minha mãe por me proporcionar oportunidade de estudo e ser um exemplo de perseverança.

Obrigado! 


\section{Agradecimentos}

Ao Prof. Heitor por acreditar no meu potencial e me dar oportunidade e meios de realizar o presente trabalho.

À Coordenação de Aperfeiçoamento de Pessoal de Nível Superior (CAPES) pelo apoio financeiro.

Ao Instituto de Medicina Tropical (IMTSP), à Faculdade de Medicina da Universidade de São Paulo (FMUSP) e ao Instituto de Ciências Biomédicas da Universidade de São Paulo (ICB-USP) por ceder espaço e recursos para a realização do presente trabalho.

À Elaine Raniero Fernandes por me ajudar com toda a parte histológica do trabalho.

Ao Daniel Perez Vieira por me ajudar na citometria de fluxo.

À dona Fran por sempre limpar a minha bagunça.

Ao Luciano por sempre conseguir todos os reagentes que necessitei durante o trabalho.

Ao Ângelo Lindoso, à Vera e à Tânia do IMTSP por me iniciarem na citometria de fluxo.

Aos colegas do Laboratório de Virologia do IMTSP, pela ajuda e espaço para a realização da citometria de fluxo.

Aos colegas do Laboratório de moléstias transmissíveis da FMUSP, pela ajuda e espaço para a realização da histologia, além dos bons momentos de descontração. 
Aos colegas do Laboratório de Protozoologia pela ajuda na realização do trabalho e pelos agradáveis momentos de descontração.

À Juliana Meirelles Machado pelo incentivo e apoio nos momento de indecisão e desanimo.

Aos meus amigos que sempre me incentivaram e acreditaram no meu potencial.

E a todos que, direta ou indiretamente, me ajudaram a realizar o presente trabalho. 


\section{Resumo}

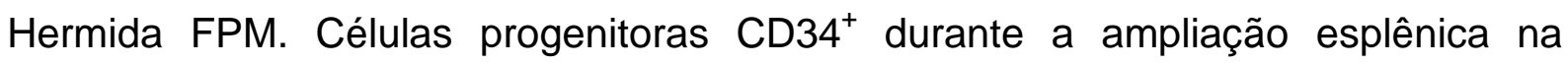
malária experimental de roedores [Dissertação]. São Paulo: Instituto de Ciências Biomédicas da Universidade de São Paulo; 2007.

A malária é uma doença causada por plasmódios, cujo controle depende do baço. Crucial no controle da malária, ele é responsável pelo clareamento dos parasitas que se dá através da rede de filtração. $O$ aumento da parasitemia implica na ampliação dessa rede para garantir a resolução da infecção. A ampliação envolve células progenitoras endoteliais e hematopoiéticas que apresentam o antígeno CD34 na sua superfície. Nós estudamos a distribuição e a quantidade de células CD34 ${ }^{+}$ em baços de roedores durante a infecção por malárias experimentais, visando compreender a participação destas na ampliação do baço e no controle da infecção. Grupos de camundongos C57BI/6j foram infectados com $10^{6}$ parasitas de 2 cepas de Plasmodium chabaudi, a CR, auto-controlável, e a AJ, usualmente letal, e de 1 cepa letal de Plasmodium berghei, a ANKA. A parasitemia foi acompanhada diariamente. Periódicamente, os baços foram pesados e processados para histologia e citometria de fluxo. A proporção entre as polpas esplênicas foi determinada pela histologia convencional. No modelo não letal, o arranjo entre as polpas é mantido durante a ampliação do baço, o que não é observado nos modelos letais. Focos de hematopoiese extramedular e de centros germinativos são observados em todos os modelos. A distribuição das células $\mathrm{CD} 34^{+}$mostrou uma maior intensidade na polpa vermelha no $4^{\circ}$ dia da infecção em todos os modelos. O mesmo fato ocorre no $8^{\circ}$ dia da infecção, porém as células CD34 ${ }^{+}$apresentam uma marcação individual muito mais fraca, sugerindo uma possível diferenciação em outras linhagens celulares. As células $C D 34^{+}$livres surgem com uma onda no $4^{-}$dia da infecção em todos os modelos. Sua quantidade é similar entre as cepas de $P$. chabaudi, mas diferente no $P$. berghei, que apesar disso, não mostra controle da parasitemia. Neste trabalho, o influxo de células $\mathrm{CD}_{3} 4^{+}$no baço não se relaciona com o controle da infecção.

Palavras-chave: Malaria de roedores. Baço. Hematopoiese. CD34. Células tronco. Progenitoras hematopoiéticas. 


\begin{abstract}
Hermida FPM. CD34+ progenitor cells during spleen amplification in experimental rodent malaria [Master Thesis]. São Paulo: Instituto de Ciências Biomédicas da Universidade de São Paulo; 2007.

Malaria is caused by Plasmodium sp., which control by the host depends on the spleen. Crucial in malaria control, this organ is responsible for parasite clearing, which is achieved by a filtration network. The increase of parasitemia implies in amplification of this network to warranting the control of the infection. This amplification involves endothelial and myeloid progenitor cells, which presented the CD34 antigen in their surface. We studied the distribution and amount of CD34 ${ }^{+}$cells in the spleen of mice infected with rodent malaria, to define the role of those cells in spleen amplification and infection control. Groups of C57BI/6j mice were infected with $10^{6}$ parasitized RBC of 2 strains of Plasmodium chabaudi, CR, self resolving, and AJ, lethal, and lethal strain of Plasmodium berghei, ANKA. Parasitemia was followed daily. Sequentially, the spleen was weighted and processed for histology and flow cytometry. Proportion of spleen pulps was determined by morphometry in usual histology. In the self controlling strain, the spleen structure was maintained during spleen amplification, not seen in lethal models. Hematopoiesis foci and germinal centers were observed in all models. The distribution of $\mathrm{CD} 34^{+}$cells was increased in the red pulp in the $4^{\text {th }}$ day p.i., in all models. At the $8^{\text {th }}$ day p.i., CD34 ${ }^{+}$staining was faint in most cells of the red pulp unclear, suggesting a differentiation of red pulp infiltrating cells in committed cell lineages. By flow cytometry, free CD34 ${ }^{+}$cells appear like a wave at the $4^{\text {th }}$ day p.i. in all models. $P$. chabaudi models presented the same level of those cells, which was larger in the $P$. berghei mice, despite absence of malaria control. In the present work, increase of spleen CD $34^{+}$cells do not correlate with infection control.
\end{abstract}

Key words: Rodent malaria. Spleen. Hematopoiesis. CD34. Stem cell. Hematopoietic progenitor. 


\section{Introdução}

Os principais agentes causadores da malária humana são o Plasmodium vivax, que é mais freqüente e benigno no Brasil, e o Plasmodium falciparum, de maior gravidade e responsável por mais de um milhão de mortes por ano no Mundo. A doença decorre do parasitismo das hemácias por plasmódios, com grande morbidade e mortalidade, cujo controle depende de um baço intacto (Engwerda et al., 2005). A maioria dos pacientes apresenta um controle espontâneo da infecção; contudo, uma fração dos pacientes apresenta doença grave, com grande letalidade em crianças (Uneke, 2007). A imunidade contra esta infecção não é protetora ou duradoura, apenas é uma premonição, fazendo com que as malárias subseqüentes sejam benignas (Smith et al., 1997). Esta premonição é atribuída ao aumento do baço, presente nos pacientes após a infecção primária, e é perdida após anos fora de áreas endêmicas. Alem disso, as malárias em pacientes esplenectomizados são gravíssimas e geralmente letais (Faucher et al., 2006).

Composto por estruturas distintas e funcionalmente associadas, o baço apresenta a polpa branca, composta por células imunes, e a polpa vermelha, composta por uma rede de filtração e um depósito de sangue (Cesta, 2006). O baço é o órgão responsável pela retirada de hemácias senescentes, aberrantes e imunologicamente comprometidas, além de elementos particulados do sangue (Krücken et al., 2005). Também é um órgão essencial no controle da malária, responsável pelo clareamento dos parasitas, que se dá através da rede de filtração, localizada na polpa vermelha (Alves et al., 1996). Na malária, o rápido aumento da carga parasitária implica na necessidade de uma grande e rápida ampliação dessa rede para controlar a parasitemia e garantir a resolução da infecção (Garnica et al., 2002). A ampliação envolve a participação de vários tipos celulares, incluindo células precursoras mielóides do endotélio e de linhagens mielocíticas, que apresentam o antígeno CD34 na sua superfície (Nakayama et al., 2007). Esta glicofosfoproteína pertence à família das sialomucinas, possui peso molecular variando entre 90 e 116 kDa e está presente em células endoteliais de pequenos vasos e em células tronco/progenitoras hematopoiéticas (HSPCs). Sua presença em células ocorre nos estágios iniciais de diferenciação de células posteriormente relacionadas à 
ampliação tanto da hematopoese, como da estrutura vascular de um órgão (Krause et al., 1996).

O aumento da rede de filtração esplênica não poderia ser estudado sequencialmente em humanos, sendo necessário o uso de modelos de malárias em modelos experimentais, entre os quais, se destacam as malárias de roedores, que permitem o estudo seqüencial da evolução, tanto da parasitemia (Nitcheu et al., 2003), como da estrutura esplênica em camundongos (Weiss et al., 1986) e em ratos (Flávia-Castillo et al., 1996). Entre estas malárias, encontramos modelos que podem causar desde infecções com controle espontâneo pelo hospedeiro, como as causadas pelas linhagens AS (Balmer et al., 2000) e CR (Taylor et al., 1997) do Plasmodium chabaudi chabaudi, até modelos de evolução uniformemente letal, como os induzidos pelas linhagens ANKA (Pamplona et al., 2007) e NK65 (Suzuki et al., 1987) de Plasmodium berghei, ou ainda pela linhagem AJ do Plasmodium chabaudi chabaudi (Long et al., 2006).

Nestes modelos, pela possibilidade de esplenectomia, foi possível identificar a função esplênica de forma grosseira. Assim, foi possível identificar uma imunopatologia relacionada à função esplênica, com maior sobrevida dos animais esplenectomizados desafiados por $P$. yoelli 17XL (Weiss, 1989) e por P. berghei, enquanto que em outros modelos a esplenectomia promovia a incapacidade de controle da infecção, causando morte rápida no animal (Eling, 1980).

Além disso, estudos com identificação de populações celulares durante a infecção malárica em modelos experimentais concentraram-se em células da resposta imune adaptativa ou da função efetora. Os estudos iniciais concentraramse na resposta fagocítica, ampliada rapidamente na malária (Shear et al., 1979), mas a seguir, eles passaram a analisar a resposta imune adaptativa, com estudos sobre as populações linfocitárias T (Marsh e Kinyanjui, 2006), desde quantificação apenas (Ing et al., 2006), até reconstrução esplênica seletiva (Leisewitz et al., 2004). Estudos em animais geneticamente modificados também se concentraram apenas no estudo da resposta efetora, em animais deficientes de Interferon ou iNOS (Garnica et al., 2003), ou deficientes em subgrupos de populações celulares (Stevenson e Riley, 2004). 
Assim, os mecanismos que controlam a ampliação e organização esplênica não foram estudados, o que é fundamental para o entendimento dos processos envolvidos no controle espontâneo da malária ou mesmo após terapia adequada. Este tipo de estudo depende da compreensão de como as células progenitoras migram ou se instalam no órgão, permitindo sua ampliação. Estudo das quimiocinas de células progenitoras mostrou uma produção temporal organizada em modelos de controle espontâneo, ausente em modelos letais (Garnica et al., 2002). O estudo das populações celulares foi relacionado à resposta imune adaptativa, em especial ao contingente $\mathrm{CD}_{11 \mathrm{C}^{+}}$ou dendríticas mielóides diferenciadas (Garnica et al., 2005). Estas células vão favorecer a resposta imune adaptativa ou participar na apresentação de antígenos e seleção de células imunes, envolvendo basicamente a polpa branca esplênica (Sponaas et al., 2006). A ampliação da rede de filtração esplênica ou do componente fagocítico depende do crescimento e diferenciação dos cordões de Billroth da polpa vermelha esplênica, e as células envolvidas nesta ampliação devem resultar em novas estruturas vasculares para filtração. O estudo de células que vão dar origem a macrófagos e estruturas endoteliais seria essencial para a compreensão dos fenômenos envolvidos na rápida ampliação da rede de filtração esplênica. Além disso, este grupo celular também participa na hospedagem de células hematopoiéticas para produção de sangue, que seria essencial para a reposição das células do sangue destruídas pela infecção malárica. Estas atividades estão presentes em células progenitoras que apresentam caráter mais primitivo e a presença do marcador CD34. O estudo das células $\mathrm{CD}^{+} 4^{+}$se torna importante devido à participação de células progenitoras hematopoiéticas na hematopoiese extramedular que ocorre em órgãos como o baço e o fígado (Kiel et al., 2005).

Assim, acreditamos crucial o entendimento da distribuição, migração e a proliferação de células $\mathrm{CD} 4^{+}$em baços de roedores durante a infecção por diferentes malárias experimentais, letais e não letais, por imunohistoquímica e citometria de fluxo, visando compreender a participação destas células na ampliação do baço e no sucesso do controle da infecção. 


\section{Objetivos}

\subsection{Objetivo geral}

Nesta dissertação pretendemos estudar a participação de células

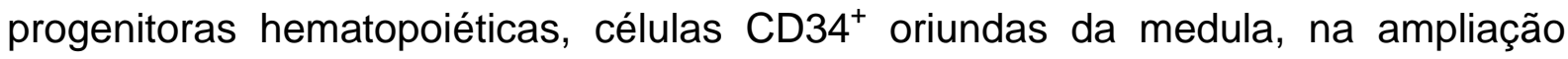
seqüencial do baço de camundongos infectados com diferentes malárias experimentais.

\subsection{Objetivos específicos}

Apresentar o estado da arte do conhecimento sobre o baço, sua ampliação em malária humana e experimental e participação de células progenitoras.

Estudar a evolução do peso do baço e de suas polpas em malárias de roedor com diferentes evoluções.

Estudar por citometria de fluxo a quantidade de células CD34+ no baço durante malárias de roedor com diferentes evoluções.

Estudar por imunohistoquímica a distribuição das células CD34+ no baço durante malárias de roedor com diferentes evoluções. 


\section{Revisão de literatura}

A malária, uma doença infecciosa que tem como agente etiológico os protozoários do gênero Plasmodium sp., é considerada a maior endemia do mundo. Segundo a Organização Mundial da Saúde (WHO, 2007), essa doença é endêmica em 105 países, aproximadamente 40\% da população mundial habita áreas de risco, e são registrados de 300 a 500 milhões de casos clínicos e mais de 1,5 milhões de mortes por ano, sendo as crianças com menos de 5 anos e as mulheres grávidas as principais populações afetadas. O continente africano é responsável por quase $90 \%$ dos casos mundiais de malária, mas ela também ocorre em outras regiões do mundo, como na América do Norte (México), América Central, América do Sul (principalmente na Bacia Amazônica), Caribe (República Dominicana e Haití), África, Ásia (Subcontinente Indiano, Sudeste Asiático e Oriente Médio), Europa Oriental e Oceania. O risco de aquisição de malária não é uniforme dentro de um mesmo país e, freqüentemente, é desigual para locais situados em uma mesma região, além de sofrer variações com as estações do ano e ao longo do tempo.

O aumento da malária no mundo é atribuído à alta resistência dos parasitas às drogas antimaláricas, ao aumento da resistência do mosquito vetor da doença ao inseticida e as espécies distintas do plasmódio (Greenwood et al., 2005). A situação da malária parece piorar, em especial, nas "fronteiras" de desenvolvimento econômico da América do Sul e do Sudeste da Ásia. Os problemas são mais graves em áreas de conflitos armados e deslocamento de refugiados (Centro de Informação em Saúde para Viajantes, Cives, 2007).

No Brasil, cerca de 500.000 novos casos de malária foram registrados anualmente na década de noventa, embora isto esteja em decaimento aparente (Bértoli e Moitinho, 2001). De 1999 a 2004, houve uma redução no número de casos de malária, diminuição dos municípios de alto risco (Incidência Parasitária Anual IPA acima de 49,9 casos/1.000 habitantes), de internações e de óbitos por malária. Aproximadamente $99,5 \%$ dos casos de malária no Brasil ocorrem na Amazônia Legal, que é composta pelos estados do Acre, Amapá, Amazonas, Pará, Rondônia, Roraima, Tocantins, Mato Grosso e Maranhão (Figura 1). Devido a sua ampla 
incidência e aos efeitos debilitantes, a malária é a doença que mais contribui para a decadência da população humana da Região Amazônica, além de reduzir os esforços das pessoas para desenvolver seus recursos econômicos, capacidade produtiva e melhorarem suas condições de vida. Apesar de estar diminuindo, a incidência da doença na Amazônia continua elevada em 2004 (IPA 19,9/1.000), prejudicando o nível de saúde da população e o desenvolvimento socioeconômico da região. O grande fluxo migratório da Região Amazônica para outros estados brasileiros, com potencial malarígeno, tem levado, nos últimos anos, ao surgimento de surtos de malária, como registrado recentemente no Paraná, Mato Grosso do Sul, Goiás, São Paulo, Rio de Janeiro, Minas Gerais, Ceará e Bahia (Ministério da Saúde, 2007).

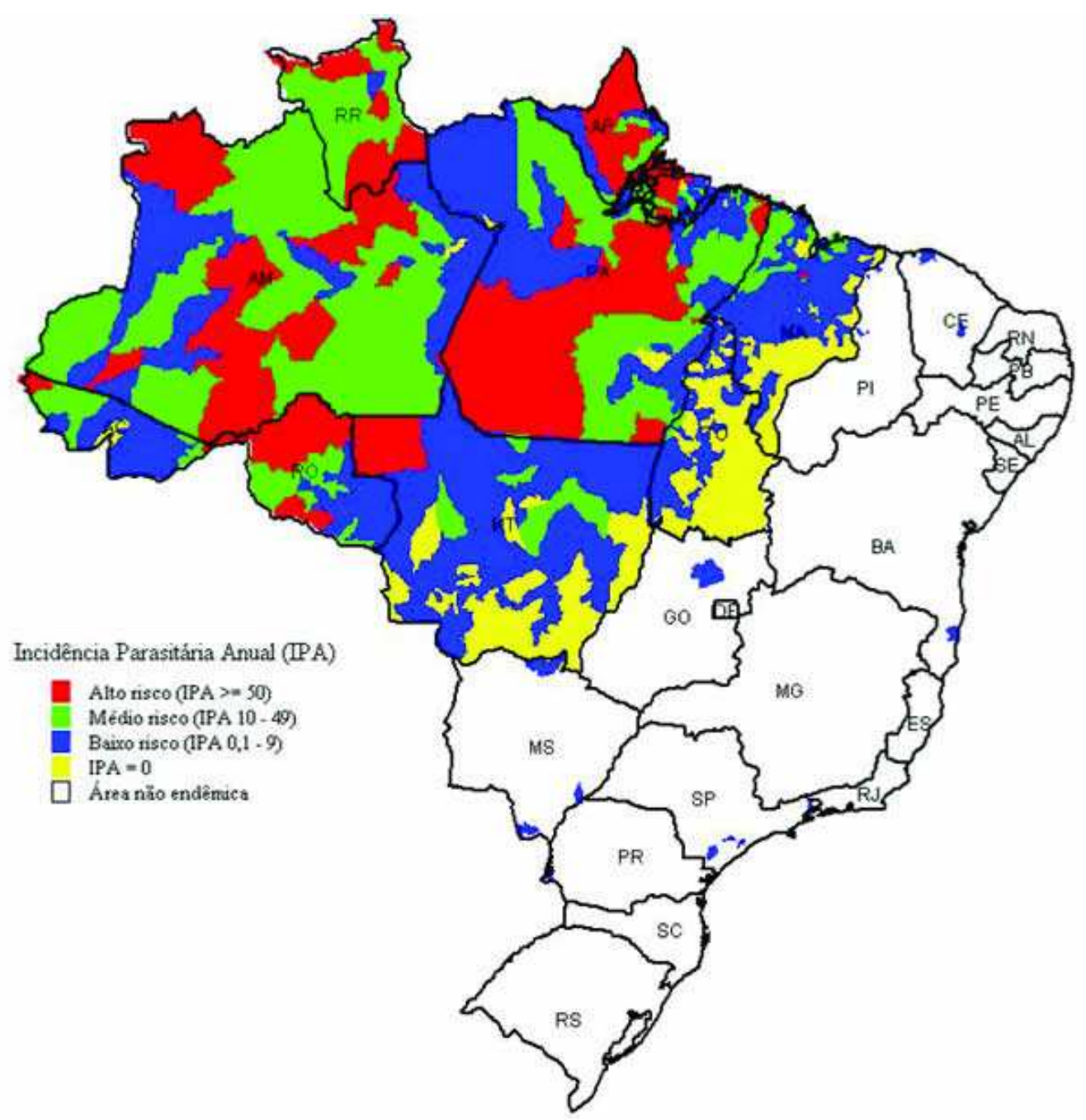

Figura 1 - áreas do Brasil com incidência de malária.

Fonte: Secretaria Executiva de Saúde Pública do Pará (sespa). 
Esses protozoários do gênero Plasmodium, assim como outros protozoários parasitas de importância médica e veterinária que pertencentes a outros gêneros, como o Toxoplasma, Theileria, Eimeria, Babesia e Cryptosporidium, pertencem ao filo Apicomplexa, um dos muitos filos do reino protozoa; e que possui mais de 5.000 espécies, sendo a imensa maioria parasitas intracelulares obrigatórios. (Sultan et al., 1997). Esses parasitas possuem ciclo de vida complexo, como alguns, incluindo Toxoplasma, Eimeria, e Cryptosporidium, onde ocorre a passagem direta entre hospedeiros vertebrados; contudo, outros, como o Plasmodium, ocorre o envolvimento de um vetor artrópode para transmitir o parasita para o hospedeiro vertebrado durante o repasto sanguíneo. Independente das diferenças entre a forma de transmissão, todos os parasitas pertencentes ao filo Apicomplexa possuem características comuns, como a presença do complexo apical, que é uma estrutura especializada ativa, responsável pelo processo de invasão da célula hospedeira. Esta estrutura é formada por várias organelas, como a roptria, o micronema, os anéis polares e os grânulos densos (Cowman e Crabb, 2006).

As espécies de Plasmodium sp. que são infectantes para o homem são: Plasmodium vivax, Plasmodium falciparum, Plasmodium malariae, e Plasmodium ovale (Sucen, 2001). A primeira espécie está presente em regiões tropicais e temperadas, com uma grande distribuição no Brasil; é a espécie responsável pela maioria dos casos clínicos de malária e sua infecção, que raramente é fatal, causa ao homem uma febre terçã benigna (Camargo et al., 1996). A segunda espécie está presente na África, no sudeste asiático, e em menor freqüência, no Brasil; é a responsável pela forma mais severa da doença e sua infecção, que pode ser fatal, causa ao homem uma febre terçã maligna (Satpathy et al., 2004). As outras duas espécies causam ao homem uma doença moderada e estão presentes na África, no sudeste asiático e em poucos casos no Brasil, no caso do Plasmodium malariae, e na África, no caso do Plasmodium ovale (Scerbaviciene e Pilipavicius, 1999).

Os sintomas clássicos da malária são: febre, dor de cabeça, calafrios, tremores, dores musculares, dores articulares, fraqueza, tosse, diarréia, vômitos e dores abdominais. No caso da malária severa, complicações como anemia, insuficiência renal, edema pulmonar, colapso circulatório, convulsões e malária cerebral são observados, e podem levar a morte (WHO, 2007). Porém, apesar de 
possuírem sintomas em comum, cada uma das espécies citadas acima causa um conjunto de sintomas único no homem, levando este a apresentar patologias distintas de acordo com a espécie infectante (Taylor e Strickland, 2000). O que acaba contribuindo para o pouco conhecimento das patologias causadas por cada espécie é a dificuldade na identificação das espécies pelas metodologias diagnósticas mais comuns e utilizadas, como a microscopia de luz; isso leva a uma relação equivocada entre a patologia e a espécie (Mueller et al., 2007).

Estes parasitas são transmitidos pelos mosquitos fêmeas do gênero Anopheles sp., quando estas realizam seu repasto sanguíneo. No Brasil, o Anopheles darlingi é a espécie de maior importância epidemiológica pela sua abundância, pela sua ampla distribuição no território nacional, atingindo todo o interior do País, pelo seu alto grau de antropofilia e endofagia e pela sua capacidade de transmitir diferentes espécies de Plasmódio. Tem como criadouros preferenciais: água limpa, de baixo fluxo, quente e sombreada, situação muito freqüente na Região Amazônica (Ministério da Saúde, 2007). O Anopheles aquasalis, que se prolifera em coleções de água salobra, tem predominância sobre o Anopheles darlingi na faixa litorânea, e apresenta maior atividade durante a noite, no crepúsculo e ao amanhecer e, geralmente picam dentro das habitações (Cives, 2007).

O ciclo de vida do parasita no hospedeiro vertebrado inicia-se nesse momento, onde as formas esporozoítas do parasitas presentes na saliva do mosquito são inoculadas na corrente sanguínea do hospedeiro (Figura 2). Estas formas chegam, através da circulação sangüínea, até os hepatócitos e invadem essas células para iniciar o ciclo hepático ou pré-eritrocítico da doença. Dentro dos hepatócitos, os esporozoítas se transformam em esquizontes, que após uma reprodução assexuada por esquizogonia, originam as formas merozoítas. Estas formas, ao serem liberadas na corrente sanguínea, invadem as células vermelhas do sangue e iniciam assim o ciclo sanguíneo ou eritrocítico da doença. Dentro dos eritrócitos, os merozoítas se transformam em trofozoítas e pré-esquizontes, que sofrem esquizogonia e liberam mais merozoítas no sangue. Em algum momento do ciclo sanguíneo ou eritrocítico, algumas formas trofozoítas originam os gametócitos, que são ingeridos pelo mosquito durante o repasto sanguíneo e iniciam dentro deste, após a meiose, o ciclo esporogônico ou sexuado da doença (Greenwood et 
al., 2005). Como o Plasmódio está presente na circulação sangüínea durante a infecção, a transmissão da malária também pode ocorrer a partir de transfusões de sangue, de transplantes de órgãos, da utilização compartilhada de seringas por usuários de drogas endovenosas ou da gestante para o filho (malária congênita) antes ou durante o parto (Cives, 2007).

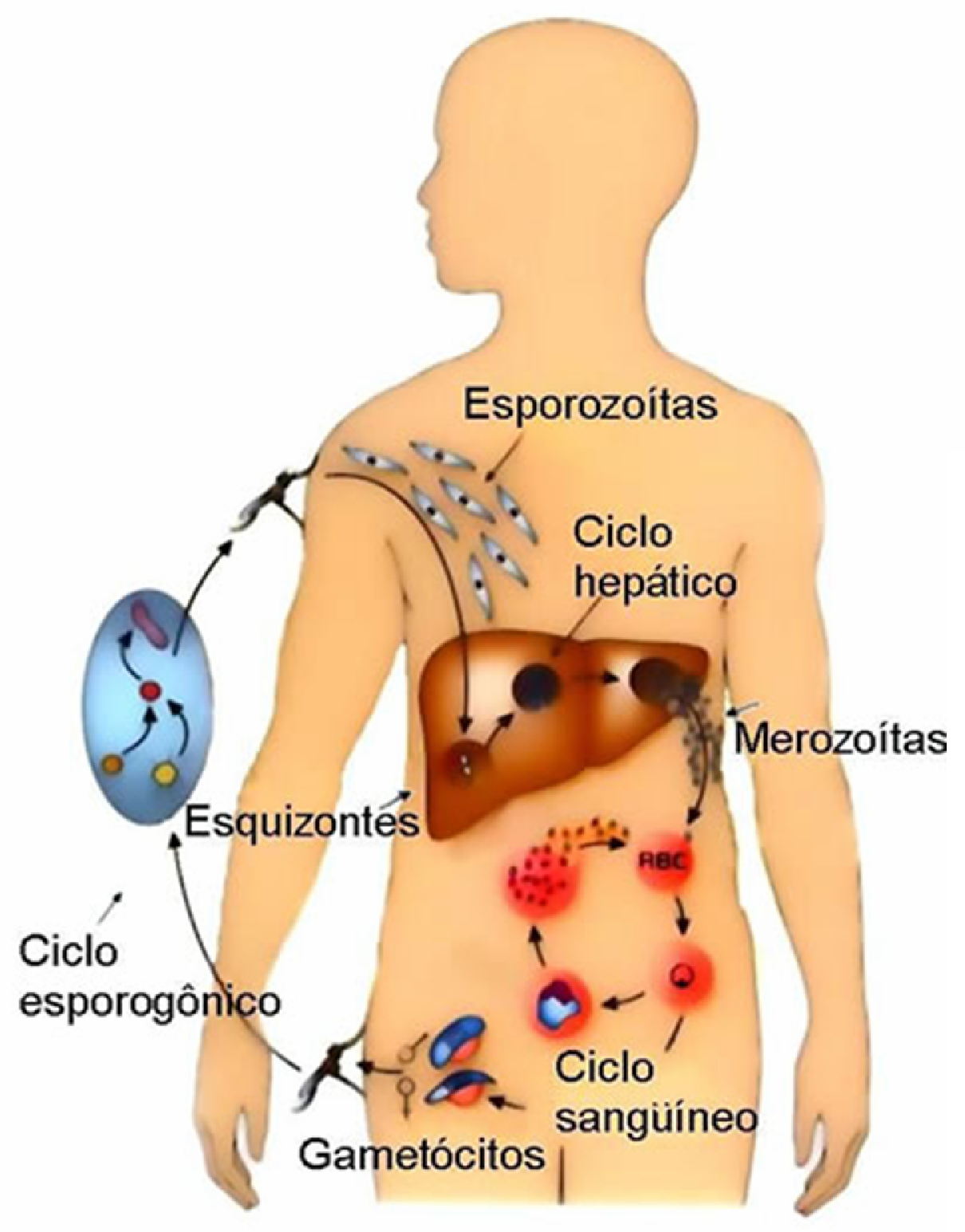

Figura 2 - ciclo de vida do Plasmódio.

Fonte: adaptado de Richie e Saul, 2002.

A transmissão da malária depende assim da população suscetível, do agente etiológico e do vetor, além das condições ecológicas, geográficas, econômicas, 
sociais e culturais (Ministério da saúde, 2007). Em áreas holoendêmicas de malária, o índice esplênico em crianças é maior que $75 \%$ e a transmissão é intensa e continua, ocorrendo uma considerável morbidade e mortalidade entre crianças de 2 a 3 anos, seguida da aquisição de uma sólida imunidade. Em áreas hiperendêmicas, há um índice esplênico maior que $50 \%$ e menor que $75 \%$ em crianças e maior que $25 \%$ em adultos, e a transmissão é intensa, mas sazonal, com baixa aquisição de imunidade e malária sintomática em todas as faixas etárias. Já em áreas hipoendêmicas, o índice esplênico é menor que $10 \%$ e a transmissão é baixa (Wickramasinghe e Abdalla, 2000).

A impossibilidade de realizar estudos seqüenciais em humanos para uma maior compreensão da sucessão de eventos que ocorrem durante a malária, impõe pesquisar modelos experimentais que reproduzam a doença humana. Entre os modelos de malária experimentais, os roedores são os que reproduzem melhor as características clínicas e patológicas da doença humana (Nitcheu et al., 2003). Contudo, não existe um modelo de roedor que reproduza todas as características da malária humana em termos clínicos, patológicos, bioquímicos e imunológicos, apenas com aspectos isolados adequadamente simulados (Hunt e Grau, 2003). A relação plasmódio-hospedeiro é muito específica.

Os Plasmodium que parasitam roedores pertencem ao subgênero Vinckeia, e são oriundos da África (Wheeler et al., 2000). Dentro desse subgênero, existem cinco espécies parasitas de roedores, sendo uma o Plasmodium atheruri, que parasita o porco-espinho Atherurus africanus na natureza e é infectante em hamsters, camundongos e ratos esplenectomizados, e em 2 exóticos roedores de fácil criação em cativeiro, o Calomys callosus e o Meriones unguiculatus (Landau et al., 1983); e 4 outras que estão divididas em dois grupos: o grupo berghei, constituído pelo Plasmodium berghei e pelo Plasmodium yoelii, e o grupo vinckei, constituído pelo Plasmodium chabaudi e pelo Plasmodium vinckei. Estas últimas espécies parasitam ratos de bosque cerrado, como o Grammomys surdaster e o Thamnomys rutilans (Perkins et al., 2007).

O Plasmodium berghei, descoberto em 1948 por Vinckei e Lips na saliva do mosquito Anopheles dureni millcampsi e no sangue do seu hospedeiro vertebrado Grammomys surdaster (Vinckei e Lips, 1950), foi posteriormente adaptado à 
infecção em camundongos pela forma sangüínea, o que facilitou os estudos experimentais, não necessitando mais dos esporozoítos do mosquito (KillickKendrick, 1974). Algumas cepas dessa espécie, como a ANKA, apresentam aspectos da patogenia da anemia severa e da malária cerebral, mas os mecanismos que levam as complicações ainda não estão totalmente elucidados (Nitcheu et al., 2003). Esse plasmódio parasita reticulócitos e outras células vermelhas jovens, mas na ausência destas, também parasita células vermelhas maduras. Por fazer esquizogonia na medula óssea, o $P$. berghei causa uma infecção letal em camundongos. O poliparasitismo e a hipertrofia de hemácias são comuns (KillickKendrick, 1974) e as infecções sangüíneas são geralmente assíncronas, com parasitemia alta (Killick-Kendrick e Warren, 1968). Essa espécie é usada para estudos de triagem de fármacos, patogenia de doença severa e para modelos de malária cerebral, em camundongos CBA/Ca (Stoltenburg-Didinger et al., 1993; Lou et al., 2001; Combes et al., 2006). Essa espécie apresenta ainda outra cepa letal, chamada NK65 (Perkins et al., 2007), e uma subespécie chamada yoelii (Wheeler et al., 2000).

O Plasmodium chabaudi, descoberto em 1965 no roedor africano Thamnomys rutilans, tem preferência por invadir hemácias maduras, havendo uma sincronia durante o ciclo assexuado, sem hipertrofia das células infectadas ou poliparasitismo (Landau e Killick-Kendrick, 1966). É utilizado em estudos da resposta imune efetora, por apresentar um controle espontâneo da doença em algumas cepas (Balmer et al., 2000), e por ter sua patologia seqüencial definida (Andrade Junior et al., 1991). Essa espécie está dividida em duas subespécies: a primeira é a adami, de controle espontâneo, e a chabaudi, que possui cepas como a AJ (Long et al., 2006), usualmente letal, e as AS, CB (Perkins et al., 2007) e CR (Taylor et al., 1997), que são auto-controláveis.

Durante a malária humana, se observa na ausência do baço, uma dificuldade em realizar o clareamento do sangue, em controlar a infecção e evitar reincidência da doença (Faucher et al., 2006). O procedimento de remoção desse órgão vem aumentando em áreas endêmicas de malária e causa aos pacientes mais suscetíveis severas infecções por bactérias e parasitas, como na malária (Petithory et al., 2005). Em pacientes esplenectomizados com malária por $P$. falciparum, o 
risco de doença é maior e com mais severidade, apresentando maior carga parasitária e eventuais mortes, apesar da administração correta de tratamento (Demar et al., 2004; Bach et al., 2005).

Camundongos sem baço estruturado por asplênia congênita, ou esplenectomizados, ou ainda esplenectomizados com reconstituição através de injeção de células esplênicas, não conseguem resolver a infecção e apresentam alta mortalidade durante primo infecções geralmente auto-controláveis por $P$. chabaudi adami e $P$. yoelii. Após o tratamento com antimalárico e reinfecção, apresentam uma infecção mais branda, semelhante a um camundongo intacto (Oster et al., 1980). Contudo, em infecções por $P$. berghei em diversas linhagens de camundongos esplenectomizados, algumas apresentaram maior sobrevida após o procedimento, com redução no pico da parasitemia e do hematócrito, ausência de atrofia do timo e aumento no peso do fígado, indicando uma possível participação do baço na patologia da malária e contribuição para a morte (Eling, 1980).

O mecanismo efetor competente para o controle do parasita é dependente do baço, um órgão crucial no controle da malária. O baço é um órgão complexo com diversas funções, como clareamento de eritrócitos senscentes ou aberrantes e fagocitose de elementos particulados circulantes; ele também possui, associado a essas funções, uma região de células imunológicas que interage com esta eficiente capacidade circulação e concentração de antígenos estranhos para iniciar uma resposta imunológica. O baço é um órgão linfóide secundário, que junto com os linfonodos e os tecidos linfóides associados com mucosas, tem a função de promover e sustentar a interação entre antígenos, células apresentadoras de antígeno e linfócitos, para resultar numa estimulação e proteção imunológica de longa duração (Drayton et al., 2006).

Apesar de ser um órgão linfóide secundário, sua origem é distinta dos demais, como linfonodos que se originam inicialmente com o aparecimento de vasos linfáticos. O baço se inicia com a aparição de células progenitoras mesodermais dentro do mesogástrio dorsal, que será o futuro omento, e adjacentes ao estômago e ao pâncreas dorsal. Com a expressão dos genes Tlx1 (Hox11), Bapx1 (Nkx3.2), Wt1, Tcf21 (Pod1/Capsulin), Nkx2.5, Pbx1 e Sox11 nessas células mesodermais, inicia-se um processo de proliferação, crescimento e desenvolvimento de uma 
adequada estrutura esplênica que, posteriormente, será envolvida por um envelope mesotelial que dará origem a cápsula esplênica (Brendolan et al., 2007).

Esse órgão é composto por estruturas distintas e funcionalmente associadas, que são sustentadas por uma rede altamente especializada de células reticulares e suas fibras. Uma delas é a polpa branca, que é composta por um folículo linfóide e por uma bolsa periarteriolar linfóide (PALS). O folículo é formado por células $B$ foliculares, células dendríticas foliculares e células estromais; rodeada por essa estrutura esta a PALS, formada por células T, células dendríticas, células estromais e por uma arteríola eferente.

Outra estrutura do baço é a polpa vermelha, representada por uma rede contrátil de vasos, que permite a filtração e armazenamento do sangue, composta por células reticulares, células endoteliais e macrófagos. Entre essas duas polpas, existe a zona marginal, que consiste em um seio revestido por células endoteliais, e que permite um fluxo rápido; também compõem essa zona células dendríticas, macrófagos metalofílicos marginais, macrófagos da zona marginal, células $B$ da zona marginal (Martin e kearney, 2002; Pillai et al, 2005) e células T (Engwerda et al., 2005). Neste órgão, existem duas regiões de intensa atividade fagocítica: a zona marginal, responsável pela retirada de partículas inertes, bactérias e vírus, e a rede de filtração, responsável pela remoção de eritrócitos senescentes ou aberrantes (Krücken et al., 2005).

A circulação esplênica ocorre por duas vias de circulação "aberta": uma rápida, onde passa $90 \%$ do sangue que entra no baço e possui um hematócrito igual ao do sangue arterial, e uma lenta, onde passa $10 \%$ do sangue que entra no baço e que possui um hematócrito duas vezes maior do que o sangue arterial (Groom et al., 1991). Existem ainda vias rápidas de circulação fechada, onde os capilares se comunicam diretamente com os vasos venosos; e que são abundantes em algumas espécies, como no cão, escasso em outras, como no homem, e ausentes em espécies que possuem baço não sinusal (Schmidt et al., 1993).

Para direcionar o sangue na circulação aberta do baço, existem células caracterizadas pela intensa ativação, com proeminente nucléolo, espaços perinucleares dilatados, extenso retículo endoplasmático e hialoplasma denso, 
denominadas células de barreira. Elas formam canais que guiam o sangue pelas rotas que compõem a circulação esplênica, protegendo os sítios de hematopoiese localizados na polpa vermelha, e promove a aderência de eritrócitos e macrófagos para auxiliar no processo fagocítico; além de impedirem que o sangue penetre na polpa branca, e assim, permitir que esta construa uma resposta imunológica adequada. Elas também dividem a polpa branca em compartimentos, permitindo um grande contato entre porções da mesma, e recobrem os vasos esplênicos para impedir que o sangue saia por fendas ou aberturas endoteliais e garantir o fluxo sanguíneo. Em situações normais, a quantidade de células de barreiras é pequena, mas situações de stress, como na malária não letal, o número dessas aumenta consideravelmente; contudo, em modelos letais de malária, é sugerido que a quantidade de células de barreira não é tão satisfatória como em modelos não letais, mostrando uma falha no direcionamento do sangue (Weiss, 1990; Alves et al., 1996).

O sangue, oriundo dos vasos arteriais, passa pelos capilares e cai no seio marginal, onde preenche todo este espaço circunferencial antes de entrar na zona marginal. Seguindo da zona marginal, a maior parte do sangue segue pela via rápida, que consiste em rotas curtas, formadas pelas células de barreira, pela rede de filtração e segue para as fendas interendoteliais (IES), localizadas no seio venoso. A menor parte, ao contrario da anterior, segue por grandes rotas pela rede de filtração, uma região que tem um alto hematócrito por permitir a passagem livre do plasma, até chegar na IES (Schmidt et al., 1993). A passagem pelas IES possui de 2,5 a $25 \mu \mathrm{m}$ por diâmetro. Essa medida se altera de maneira desigual e desincronizada, restringindo a passagem de células, e gerando um fluxo descontinuo que entra no seio venoso. Esse evento ocorre por meio de contrações das células endoteliais da IES e pode garantir um maior preenchimento da polpa vermelha; ele também ocorre nas células do endotélio dos capilares, que liberam para o seio marginal quantidades diferentes de fluxo sanguíneo. Uma vez nas IES, as células sangüíneas acabam se espremendo para poderem passar por essas fendas e entrar nos vasos venosos, num processo dependente da estrutura citoesquelética (Groom et al., 1991). 
Essa estrutura citoesquelética é composta por espectrina, uma molécula gigante e flexível composta por duas subunidades distintas: a aI e a $\beta I$; essas duas subunidades se entrelaçam formando um heterodímero. Essa proteína existe em longos tetrâmeros, que se formam pela auto-associação, cabeça por cabeça, dos heterodímeros. Os tetrâmeros de espectrina formam uma treliça (rede de filamentos cruzados), onde as junções estão interagindo com pequenos filamentos de actina. Essa rede está ligada a diversas proteínas transmembranicas, como a proteína integral banda $3(\lambda E 1)$ ou as glicoforinas $C$ e $D$, através de proteínas de conexão como a anquirina e a proteína 4.1. Além de ser o componente central do citoesqueleto, a espectrina também está envolvida no processo de invasão do plasmódio no eritrócito. Indivíduos com elliptocitose hereditária, uma doença causada por um completo defeito na espectrina e que é mais incidente em indivíduos negros, e indivíduos com esferocitose hereditária, uma outra doença causada por um defeito parcial na espectrina, possuem eritrócitos mais resistentes à infecção dos plasmódios. Esses eritrócitos são menos infectados e afetam o ciclo eritrocítico e o crescimento daqueles que conseguem infectar, debilitando estes para novas infecções (Dhermy et al., 2007).

O processo de invasão, assim como o processo de replicação e divisão assexuada do ciclo eritrocítico do Plasmódio, causa danos à estrutura citoesquelética da célula, alterando sua morfologia, tornando-as esféricas, aumentando a rigidez da membrana e comprometendo a sua capacidade de contração. Tudo se inicia com a invasão, que ocorre quando diversas proteínas da membrana de um merozoíto extracelular entram em contato com a superfície da célula hospedeira de forma reversível e com baixa afinidade, seguido da reorientação do parasita para liberação de mais proteínas do micronema e da roptria, promovendo a adesão da região apical, e da ligação da TRAP com actinamiosina (Sultan el al., 1997), via aldolase (Jewett e Sibley, 2003), para penetração ativa e interação da adesão extracelular com o citoesqueleto do parasita. Essa interação começa e se desfazer, através de enzimas proteolíticas, e se refazer sentido antero-posterior do parasita, empurrando o mesmo para dentro da célula hospedeira, e dando a ele um vacúolo parasitóforo formado por membrana do parasita (Cowman e Crabb, 2006). 
Após a invasão, o parasita, que está na forma de anel, começa a modificar sua célula hospedeira através da liberação de fatores remodeladores e de uma série de antígenos variáveis; e, posteriormente na forma de trofozoíto, começa ingerir abundantemente hemoglobina das células hospedeira pelo processo de endocitose. Para evitar os efeitos tóxicos da porção heme da hemoglobina, o trofozoíto polimeriza essa porção em hemozoina dentro do vacúolo alimentar e utiliza os fragmentos restantes como fonte de aminoácidos. Após consumir quase todo eritrócito, o trofozoíto se transforma em esquizonte, a membrana do vacúolo parasitóforo é rompida pela ação de enzimas proteolíticas, e alterações bioquímicas no citoesqueleto e de pressão intracelular promovem uma lise explosiva das células hospedeira, espalhando restos celulares e os merozoítos, que apresentam pouco movimento ondulante ou gliding (van Dooren et al., 2005).

Uma vez perdida a capacidade de contração, devido à invasão pelo Plasmódio, os eritrócitos parasitados não conseguem passar pelas IES e acabam retidos na zona marginal, tornando-se alvos para o sistema imune e fazendo essa área um local perfeito para eliminação do parasita (Drayton et al., 2006). Esse fato também ocorre na rede de filtração, que possui grande superfície de adesão para eritrócitos anormais (Groom et al., 1991). O aumento da parasitemia causa um grande acúmulo de eritrócitos e induz uma grande congestão do baço, que leva a uma obstrução da circulação esplênica por volta do quarto dia após a infecção e parada completa de fluxo sangüíneo no oitavo após a infecção (Krücken et al., 2005). Ao iniciar esse processo, sinais e atividades para a ampliação da rede de filtração, com influxo, proliferação e ativação de vários tipos celulares resultam numa ampliação da capacidade do baço em realizar um rápido clareamento dos eritrócitos parasitados e de controlar a malária, além de permitir a realização hematopoiese extramedular (Garnica et al., 2003).

Durante o processo de ampliação do baço que ocorre na malária, todas essas estruturas esplênicas, bem como as células que as compõem, se rearranjam, interagem entre si e migram de uma região para outra para promoverem uma maior capacidade do baço em realizar a resolução da infecção. Tal rearranjo e interação são observados em malárias tanto humanas (Urban et al., 2005) com de roedores (Leizewits et al., 2004), onde os limites entre a polpa branca e a polpa vermelha, 
assim como a zona marginal, desaparecem durante a infecção. Em infecções por $P$. chabaudi AS, ocorre um grande aumento de células nucleadas no tecido esplênico (Leizewits et al., 2004), como fagócitos $\left(\mathrm{F} 4 / 80^{+}\right)$, granulócitos $\left(\mathrm{Gr}-1^{+}\right)$(Krücken et al., 2005), células dendríticas $\left(\mathrm{CD}_{\left.11 \mathrm{C}^{+}\right)}\right.$(Garnica et al., 2005) e células B

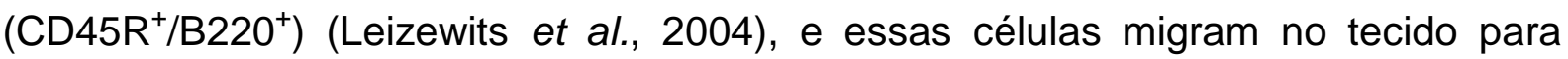
promover interações entre as estruturas do baço.

Os macrófagos $\left(\mathrm{F} 4 / 80^{+}\right)$, em infecções por $P$. chabaudi AS, migram inicialmente da polpa vermelha para a polpa branca, depois se espalham pelo tecido esplênico, e por fim retornam para a polpa vermelha; já os macrófagos da zona marginal $\left(\mathrm{ER}^{-\mathrm{TR}^{+}}{ }^{+}\right.$, que são observados entre a zona marginal e a polpa vermelha, se espalham inicialmente pelo tecido esplênico e desaparecem logo em seguida; outra população celular que se rearranja é a dos macrófagos metalofílicos marginais $\left(\mathrm{CD} 169^{+} / \mathrm{MOMA}^{+}\right)$, que formam um anel em torno da polpa branca (Krücken et al., 2005). Contudo, alguns trabalhos não registram células $\mathrm{F} 4 / 80^{+}$na polpa branca durante uma infecção por $P$. chabaudi AS (Leizewits et al., 2004). Existem ainda células como os granulócitos, que saem da polpa vermelha e se espalham pelo tecido esplênico; os reticulócitos, que também saem da polpa vermelha e migram para a zona marginal; células $\mathrm{T}$, que saem da polpa branca e se espalham pelo tecido esplênico; e as células $B$, que saem do folículo linfóide presente na polpa branca, e se concentram, no final da infecção, na zona marginal. No final do período de infecção, após todas essas migrações pelo tecido esplênico, uma intensa atividade fagocítica de hemácias infectadas é observada também na zona marginal, que no inicio da infecção ocorria preferencialmente na polpa vermelha (Krücken et al., 2005).

A migração de células dendríticas $\mathrm{CD} 11 \mathrm{c}^{+}$no tecido esplênico em infecções por $P$. chabaudi AS ocorre a partir do $5^{\circ}$ dia de infecção em direção as áreas de células T CD4 ${ }^{+}$(Leizewits et al., 2004). Nesta infecção, também se observa ao logo da infecção variações dos subtipos de células dendríticas CD11c ${ }^{+}$esplênicas, que podem ser mielóides, como as $\mathrm{CD}^{+} / \mathrm{CD}^{-} / \mathrm{CD} 11 \mathrm{~b}^{+}, \mathrm{CD}^{-} / \mathrm{CD}^{-} / \mathrm{CD} 11 \mathrm{~b}^{+}, \mathrm{CD}^{-}$

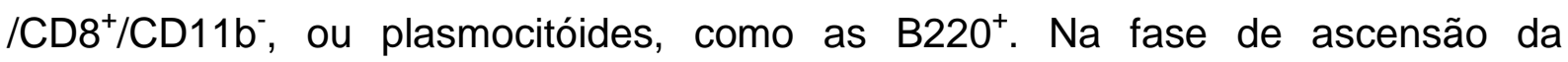
parasitemia, que vai do $2^{\circ}$ ao $5^{\circ}$ dia após a infecção, ocorre o pico de atividade de fagocítica pelas células $\mathrm{CD}_{11 \mathrm{c}^{+}}$, e os subtipos que apresentam maior atividade são 
os $\mathrm{CD}^{+}$e os $\mathrm{CD}^{+}$, e os B220+ com menor atividade (Ing et al., 2006). Já no pico de parasitemia, onde ocorre preferencialmente apresentação de antígenos e

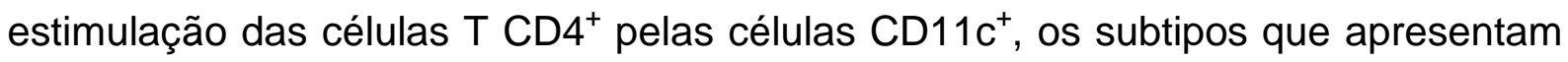
maior capacidade de realizar essas tarefas são os CD8, embora esses subtipos possuam menor quantidade de $\mathrm{MHC}$ classe II em relação as CD8 ${ }^{+}$. Esse subtipo de célula dendrítica ainda expressa IL-4 e IL-10, além de IL-2 e INF-y como as CD8 ${ }^{+}$, e contribuem no processo antiinflamatório que ocorre após o pico de parasitemia (Sponaas et al., 2006).

Em infecções por $P$. berghei, também se observa aumento na população de

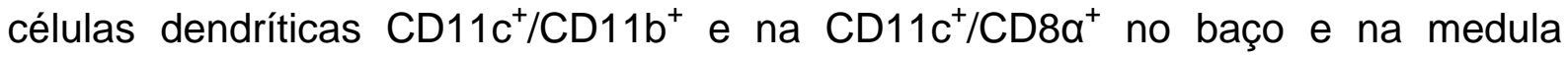
óssea, e um aumento ainda maior sobre a administração exógena de CXCL12 nos animais infectados. Essa quimiocina também aumenta a população dessas células dendríticas na medula óssea mesmo em camundongos não infectados, aumentando

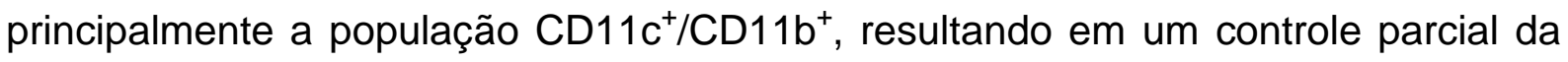
infecção (Garnica et al., 2005).

As várias formas dos plasmódios dentro do hospedeiro vertebrado estão em estreita relação com a resposta imune. Em infecções por modelos auto-controláveis de $P$. chabaudi, os esporozoítos que invadem os hepatócitos e os esquizontes gerados por eles, induzem uma resposta imune. Essa resposta pode ser por anticorpos que bloqueiam a invasão dos esporozoítos, e/ou pela produção de células NKT (Stevenson e Riley, 2004) e células T $\mathrm{CD}^{+}$e $\mathrm{CD}^{+}$que inibem 0 desenvolvimento do parasita no fígado (Belnoue et al., 2004). Na ausência desta resposta, como nas primo-infecções, dá-se inicio ao ciclo eritrocítico. $\mathrm{Na}$ fase de ascensão da parasitemia, ocorre uma resposta pró-inflamatória, com participação inicialmente dos mecanismos inatos, como as células NK e as células $T$ y $\delta$ que produzem INF-y TNF- $\alpha$ e IL-2, e como os macrófagos e as células dendríticas, que produzem IL-12, IL-15, INF- $\alpha$, TNF- $\alpha$ e NO (Langhorne et al., 2004; Stevenson e Urban, 2006).

Posteriormente, durante o pico da parasitemia, adiciona-se a participação dos mecanismos adaptativos auxiliadores e citotóxicos, como as células T CD4 ${ }^{+}$ maturadas pela interação com células apresentadoras de antígenos, que podem ser os macrófagos, células dendríticas e células $B$, e como as células CD8 ${ }^{+}$. Ambas as 
células $T$ produzem também produzem INF- $\mathrm{\gamma}$, TNF- $\alpha$ e IL-2, porém já em quantidades menos elevadas. Após o pico da parasitemia, inicia-se uma resposta antiinflamatória, com diminuição dos mecanismos inatos e adaptativos anteriores pela ação de citocinas, como IL-4, IL-10 e TGF- $\beta$ produzidas pelas células T macrófagos, e com participação das células $B$ ativadas diretamente pelas células dendríticas ou indiretamente pelas células T CD4 ${ }^{+}$(Stevenson e Urban, 2006). Este é o modelo mais aceito, embora existam outros autores que defendam a hipótese de que a resposta $T_{H} 1$ citotóxica pouco participa no controle da malária, sendo as responsáveis pela resolução a resposta inata, seguida da resposta $T_{H} 2$ humoral (Fell e Smith, 1998).

O processo esplênico de ampliação envolve a participação de vários tipos celulares, incluindo precursoras mielóides do endotélio (Hristov e Weber, 2004) e células tronco/progenitoras hematopoiéticas (HSPCs) que apresentam CD34 na sua superfície (Nakayama et al., 2007). Esta glicofosfoproteína, que pertence a família das sialomucinas e que possui um peso molecular entre 90 e $116 \mathrm{KDa}$, consiste em um grande domínio extracelular contendo uma extensa região semelhante à mucina e altamente glicosilada, seguida de uma região rica em cisteina (Krause et al., 1996).

Os genes que codificam a proteína CD34 de humanos e de camundongos são constituídos por 9 exons, do exon 1 ao 8 e um exon $\mathrm{X}$, que estão inseridos em uma região do DNA genômico de $22 \mathrm{~Kb}$, localizada no braço longo do cromossomo 1 de camundongos, e de $27 \mathrm{~Kb}$, localizada na região cromossômica 1q32 de humanos, que é uma região que contém diversos genes codificadores de moléculas de adesão. Esses genes possuem uma grande homologia e são, bem conservados no decorrer da escala evolutiva, possuindo uma homologia de 90\% no domínio intracelular, que é codificado pelo exon 8, e uma homologia de $43 \%$ no domínio extracelular. Existem duas espécies de mRNA de CD34, derivados de mecanismos de junção diferentes (Suda et al., 1992; Nakamura et al., 1993): um possui os exons do 1 ao 8 , e codifica a forma completa da proteína, que possui um total de 385 aminoácidos (aa) em camundongos, e 382 aa em humanos, e com um domínio intracelular de 73 aa; já o outro, também possui os exons do 1 ao 8 , só que com a inserção do exon $\mathrm{X}$ entre o exon 7 e o 8, codificando assim, a forma truncada da proteína, que possui um domínio intracelular de apenas 16 aa, devido ao códon 
terminal que o exon X introduz (Figura 3). Contudo, nenhuma diferença funcional é observada entre essas duas formas (Krause et al., 1996).

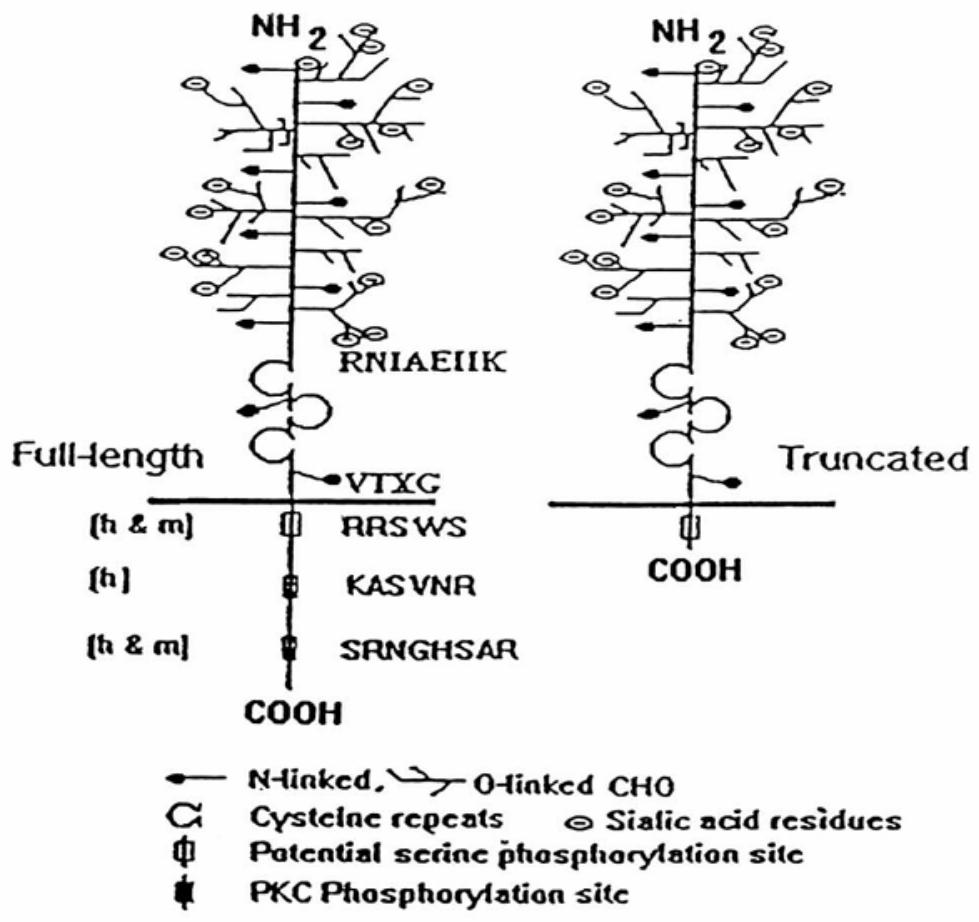

A

FULL-LENGTH CD34

B
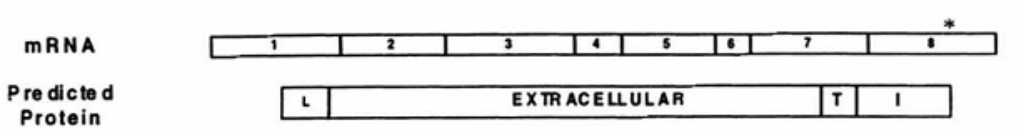

$2.5 \mathrm{~kb}$

382 aa

TRUNCATED CD34
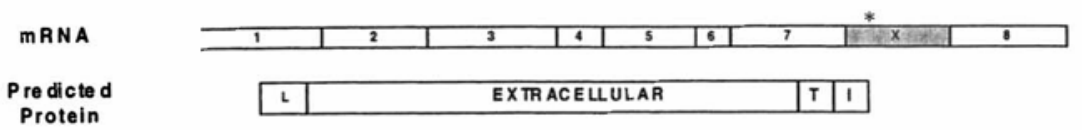

$2.7 \mathrm{~kb}$

323 aa

Figura 3 - modelo e propriedades estruturais da CD34: (A) desenho esquemático mostrando as formas completas e truncadas da proteína, incluindo os sítios previstos de glicosilação e forforilação de serina, de CD34 humana(h) e de camundongo $(m)$. A forma truncada da CD34 é apresentada para comparação. Os sítios de reconhecimento putativos conservados RNIAEIIK e VTXG devem conferir propriedades de adesão. (B) Desenho esquemático da quebra alternativa do mRNA resultante em produção de proteína completa ou truncada.

Fonte: Krause et al., 1996. 
Além de estar presente em HSPCs e em células endoteliais, a CD34 está presente também em mastócitos de camundongos (Barton e McNagny, 2006), células tronco mesenquimais, fibroblastos embrionários, algumas células em tecidos nervosos de adultos e de fetos, fígado embrionário, e em tecidos embrionários extrahepáticos, que incluem progenitoras hematopoiéticas associadas à aorta nas 5 semanas de vida em embriões humanos (Krause et al., 1996). Este marcador apresenta funções pró-adesivas, como na adesão de leucócitos em células endoteliais $\mathrm{CD}^{+} 4^{+}$de vasos, através da interação com a L-selectina; e de antiadesão, como ocorre em mastócitos de camundongos, através da inibição das moléculas a desivas pelo ectodomínio mucina das CD34. Tais funções facilitam a migração de várias precursoras hematopoiéticas para os seus respectivos nichos (Barton e McNagny, 2006).

A utilização desse marcador para células precursoras hematopoiéticas está relacionada com o fato de que sua expressão não ocorre em células maduras do sangue (Cheng et al., 1996), só em HSPCs mobilizadas (Tajima et al., 2000). Contudo, apesar da proteína $\mathrm{CD}^{+} 4^{+}$ser designada como um dos principais marcadores dessas células, alguns trabalhos mostram que células CD34 também são competentes em reconstituir tecidos em transplantes (Osawa et al., 1996; Goodell et al., 1997). Sua ausência, apesar permitir uma sobrevida em camundongos, causa diversos defeitos hematopoieticos, como diminuição do número de Unidades Formadoras de Colônia (CFU) em todos os tecidos hematopoieticos, diminuição na atividade e na capacidade, in vitro, de expansão de células progenitoras e diminuição na diferenciação de células progenitoras mielóides e eritróides (Cheng et al., 1996). Além dessas disfunções, ainda pode ocorrer defeito no recrutamento de eosinófilos para o intestino e de mastócitos para o peritônio (Barton e McNagny, 2006).

As HSPCs, que possuem de 8 a $10 \mu \mathrm{m}$, são responsáveis pela renovação de todas as células maduras do sangue (Winkler et al., 2006), e a sua freqüência em tecidos humanos é de 3,6\% na medula óssea, e 2,4\% no baço (Dor et al., 2006). Essas células podem ser identificadas por citometria de fluxo pela sua alta positividade ao CD34 e pela sua baixa rugosidade (Gratama et al., 1998). 
A maior parte dessas HSPCs estão localizadas na medula óssea. Esse micro ambiente é composto por dois nichos que se comunica entre si: um é o nicho de osteoblastos, composto por uma camada de osteoblastos que reveste a interface entre o osso e o tecido hematopoietico,contendo osteoclastos, HSPCs, células endoteliais e células neurais; e o outro é o nicho vascular, composto por HSPCs e por vasos sanguíneos com uma camada simples de células endoteliais, distribuídos entre as traves ósseas. (Li e Li, 2006). Esses dois nichos, bem como a interação entre eles, permitem uma constante renovação e circulação de HSPCs no organismo.

O nicho de osteoblastos é o local responsável pela quiescência e autorenovação das HSPCs, onde essas células aguardam algum sinal do organismo para iniciarem o processo de mobilização. Uma vez iniciado esse processo, essas células migraram para o nicho vascular, que é um local responsável pela ativação, proliferação e posterior diferenciação ou maturação dessas células. Possuindo uma camada simples de endotélio, o nicho vascular permite uma imediata resposta para a demanda fisiológica por não oferece muita resistência para a passagem de sinais que mobilizam e ativam as HSPCs, nem para a passagem das próprias HSPCs, que fazem uma migração transendotelial e caem na corrente sangüínea e migraram para o resto do organismo. As HSPCs que não se alojaram em nenhum outro tecido do organismo, retornam para o nicho de osteoblastos, num processo inverso chamado homing, e entram em estado de quiescência novamente (Kopp et al., 2005). Importante, em situações fisiológicas e principalmente em determinadas doenças, como na malária, o nicho vascular serve como um sítio alternativo para hematopoiese em órgãos como o fígado e o baço que possuem hematopoiese extramedular, pois ele também possui HSPCs em estado de quiescência e de autorenovação (Kiel et al., 2005).

As HSPCs interagem com os nichos através de moléculas sinalizadoras e adesivas. No nicho de osteoblastos, as HSPCs estão ligadas aos osteoblastos $\mathrm{N}$ caderina $^{+}$através de interações como VCAM-1 (HSPCs) e VLA-4 (osteoblastos), tmKIT e c-KIT, CXCL12 e CXCR4, Notch e Jag1, Tie2 e Ang-1, e N-caderina e $\beta$ catenina. No nicho vascular, o sinal de FGF-4 que emana forma um gradiente entre os nichos e atrai as HSPCs, que expressão FGFR1, -2, e -3; já a expressão de 
CXCL12 pelas células endoteliais promove a migração transendotelial, mediada por E- e P-selectina. Essas duas moléculas também aumentam a expressão de VCAM-1 nas células endoteliais (Yin e Li, 2006).

Existem diversos agentes mobilizadores de HSPCs: citocinas e quimiocinas, como CCL3, CXCL2, CXCL8, CXCL12, CXCR4 agonista; stress, como hormônio acetilcorticotropico (ACTH) e exercício intenso; poliânios, como sulfato de dextran, fucoidanos e ácido polimetacrílico; toxinas, como endotoxinas bacterianas; anticorpos, como anti-CD49d e anti-VCAM-1; fatores de crescimento, como G-CSF, GM-CSF, VEGF, PLGF, FGF-4, GH, ligante de KIT, ligante de Flt-3, IL-3, trombopoetina, eritropoetina, angiopoetina-1, Tie-2 e N-caderina; mielosupressores, como a ciclofosfamida (CY) e 5-fluracil (5-FU); enzimas proteolíticas, como a metaloproteinase-2 (MMP-2), MMP-9, catepsina G (CG), elastase neutrofila (NE); e integrinas e moléculas de adesão, como VLA-4, LFA-1 e osteopontina (Winkler et al., 2006; Li e Li, 2006).

Os principais mecanismos de ação desses agentes mobilizadores agem através da atração por CXCL12, bloqueio do CXCR4, da inibição da interação do VCAM-1 com o VLA-4, e da expansão e ativação de granulócitos, que promove a liberação, principalmente via neutrófilo, de enzimas proteolíticas que quebram e inativam as proteínas essenciais para a retenção das HSPCs na medula óssea, como a VCAM-1, c-KIT, tmKIT, CXC12 e CXCR4 (Winkler et al., 2006). Existem ainda, mecanismos que agem através da regulação do ciclo celular, através da $\mathrm{N}$ caderina, da angiopoetina e da Tie-2, e da formação de um gradiente, como dito anteriormente, entre o nicho vascular e o osteoblástico através do FGF-4. Há estudos que indicam um mecanismo de ação nervoso, via sistema simpático, dependente de íons de cálcio que possivelmente este mecanismo tenha ação sobre as células endoteliais do nicho vascular ( $\mathrm{Li}$ e Li, 2006).

Durante malária em humanos, a medula óssea sofre alterações na eritropoiese e em outras linhagens hematopoiéticas. Na fase aguda, a anemia é causada por hemólise periférica e por supressão da eritropoiese, que se dá pela alta produção em um curto período de TNF- $\alpha$ e INF-y e por efeito direto de produtos do parasita, como a hemozoína. Já fase crônica, a anemia é causada por disfunções e ineficiência na eritropoiese, devido ao aumento de TNF-a por longos períodos, pelo 
desbalanço entre os níveis de citocinas e pela disfunção dos macrófagos que afeta os fatores estimulatórios e inibitórios de crescimento hematopoietico. Ocorre ainda na fase crônica, a alta produção de eritropoetina, que é devido à hiperplasia eritróide (Wickramasinghe e Abdalla, 2002).

Com essas disfunções hematopoiéticas que ocorrem na medula durante a malária, os sítios com hematopoiese extramedular, como o baço, tornam-se um importante sítio de hematopoiese durante essa mesma doença. Foi observada, durante infecções com modelos letais de malaria de roedores, a hematopoiese e a eritropoiese esplênica ocorrem de maneira desorganizada e ineficiente, enquanto que, com modelos auto-controláveis, a hematopoiese e a eritropoiese esplênica possuem uma alta organização e eficiência (Garnica et al., 2002).

Tendo em vista a importância da hematopoiese extramedular realizada pelo baço durante a malária, e a relação das HSPCs CD34 ${ }^{+}$com este evento, este trabalho estuda essas células no baço durante a evolução de três malárias experimentais de roedores, $P$. berghei ANKA, usualmente letal; $P$. chabaudi CR, auto-controlável; e P.chabaudi AJ, usualmente letal, por imunohistoquímica e por citometria de fluxo. 


\section{Material e Métodos}

Todos os sais e demais reagentes utilizados foram de qualidade pró-analise, sendo a água utilizada purificada em sistema Milli-Q (Millipore Corporation, Billerica, M.A., U.S.A.), apresentando resistividade de $18,2 \mathrm{M} \Omega \mathrm{cm}$. Reagentes específicos têm sua fonte citada ao longo do texto.

\subsection{Animais experimentais}

Camundongos fêmeas isogênicos C57BL/6j, com 5 a 6 semanas de vida e com peso entre 20 e 22g, fornecidos pelo Biotério Central da Faculdade de Medicina da Universidade de São Paulo (FMUSP), foram mantidos em cabines ventiladas com ciclo circadiano invertido, dentro de gaiolas de plástico com maravalha de pinho autoclavada, e recebendo ração comercial Nuvital (Nuvital Nutrientes S/A, Colombo, P.R., Brasil) e água ad libitum. A manipulação dos animais foi conduzida de acordo com as normas de cuidados de animais de laboratório (Clark, 1996) e com os "Princípios de Ética em Experimentação Animal" (COBEA - Colégio Brasileiro de Experimentação Animal).

\subsection{Linhagens de Plasmódio}

Nos experimentos foram utilizadas 3 cepas de malária de roedores: uma é a cepa CR, que pertence à espécie Plasmodium chabaudi chabaudi e é autocontrolável e não letal; a outra a cepa $\mathrm{AJ}$, que também pertence à espécie $P$. chabaudi chabaudi e é usualmente letal; e a ultima é a cepa ANKA, que pertence à espécie Plasmodium berghei e também é usualmente letal. Essas cepas foram gentilmente fornecidas pelo Dr. David Walliker, da Universidade de Edimburgo e do Banco de Clones e Plasmódios da Organização Mundial da Saúde, e são mantidas como estabilatos em nitrogênio líquido, no Laboratório de Protozoologia do Instituto de Medicina Tropical de São Paulo, após passagens em animais controlados para infecção por Eperytrozoon coccoides (de Andrade Junior et al., 1986). 


\subsection{Infecção}

Para se obter os inóculos experimentais das 3 cepas, inicialmente os estabilatos de cada cepa foram descongelados a $37^{\circ} \mathrm{C}$ e inoculados, via intraperitoneal (i.p.), em camundongos C57BL/6j. Posteriormente, durante a fase de ascensão da parasitemia, o sangue dos camundongos foi retirado por punção cardíaca, utilizando citrato como anticoagulante, e encaminhado para a infecção dos grupos experimentais. Cada camundongo foi infectado, via i.p., com um inóculo de $10^{6}$ eritrócitos parasitados ou com a cepa $A J$, ou com a cepa $C R$, ou com a cepa ANKA, diluídos em solução fisiológica, perfazendo um mínimo de 40 camundongos para cada cepa.

\subsection{Parasitemia}

A parasitemia de todos os animais foi acompanhada diariamente $e$ determinada através de esfregaços de sangue caudal fixados com metanol absoluto e corados com Giemsa (Merk e Co., Inc., Whitehouse, N.J., U.S.A.). O sangue era obtido através de uma pequena incisão feita na ponta da cauda do camundongo. A porcentagem de hemácias parasitadas foi determinada em 500-5000 eritrócitos, utilizando uma amostragem de ao menos 10 campos em baixas parasitemias ou a proporção de 500 hemácias em parasitemias maiores que 100 hemácias parasitadas por campo.

\subsection{Sacrifício, remoção dos baços e determinação da sua massa}

Os camundongos foram sacrificados diariamente, em câmara de $\mathrm{CO}_{2}$ até o $12^{\circ}$ após a infecção. Seus baços foram removidos cirurgicamente e de forma estéril, pesados e divididos em 2 partes, sendo uma direcionada para histologia e a outra para a citometria de fluxo.

\subsection{Histologia e Imunohistoquímica}

O fragmento intacto do baço foi fixado por imersão em, no mínimo, 20 volumes de formaldeído a $4 \%$ tamponado com tampão de Sorensen $\left(\mathrm{NaH}_{2} \mathrm{PO}_{4} \cdot \mathrm{H}_{2} \mathrm{O}\right.$ 
+ $\left.\mathrm{Na}_{2} \mathrm{HPO} 4,0,02 \mathrm{M}\right), \mathrm{pH} 7.2$, por 24 horas para subseqüente inclusão em parafina. Secções com $5 \mu \mathrm{m}$ de espessura foram aderidas em lâminas silanizadas para serem coradas com hematoxilina-eosina $(\mathrm{HE})$ de rotina ou direcionadas para imunohistoquímica. As lâminas, na imunohistoquímica, foram re-hidratadas a quente, em banhos sucessivos de álcool 100\%, 90\%, 80\% e 70\%, e tratadas com hidróxido de amônia, por 30 minutos, para destruição da peroxidase endógena e com ácido oxálico, por 1 hora, para retirada do pigmento malárico. Para a recuperação de antígenos, as lâminas foram colocadas em solução Tris-EDTA, a $9^{\circ} \mathrm{C}$, por 30 minutos. Após a inativação da biotina endógena pela incubação das lâminas com estreptoavidina DAKO (DAKO Denmark A/S, Glostrup, Denmark), por 15 minutos, e com biotina (DAKO), por mais 15 minutos, as secções foram incubadas com anticorpo monoclonal de coelho contra CD34 H-140 Santa Cruz (Santa Cruz Biotechnology, inc., Santa Cruz, C.A., U.S.A.) de camundongo por 18 horas. Após lavagens, foram incubadas com anticorpo secundário policlonal contra IgG de coelho Sigma (Sigma-Aldrich Co., St. Louis, M.O., U.S.A.), produzido em cabra, e após novas lavagens, uma nova incubação foi feita com conjugado peroxidase contra IgG de cabra (Sigma) produzida em coelho. Os anticorpos adsorvidos foram revelados por oxidação, através da solução cromogênica $D A B$, composta por salina tamponada com fosfato (PBS) $\left(\mathrm{NaCl} 0,15 \mathrm{M}+\mathrm{NaH}_{2} \mathrm{PO}_{4} \cdot \mathrm{H}_{2} \mathrm{O}\right.$ $0,01 \mathrm{M}+\mathrm{Na}_{2} \mathrm{HPO} 40,01 \mathrm{M}$ ) a $1 \%, \mathrm{pH} 7,2$, contendo $1 \mathrm{mg} / \mathrm{ml}$ de 3,3'-diaminobenzidina$\mathrm{HCl}$ (Sigma), e $\mathrm{H}_{2} \mathrm{O}_{2}(0,03 \%)$. A contra-coloração foi feita com hematoxilina. Para testar a eficiência do nosso anticorpo primário, controles internos adequados, sem a utilização do mesmo, foram feitos e não mostraram reação (Quadro 1).

Quadro 1 - HE e imunohistoquímica de CD34, com e sem anticorpo primário, em baços de camundongos pré-infecção (10 e 40x).

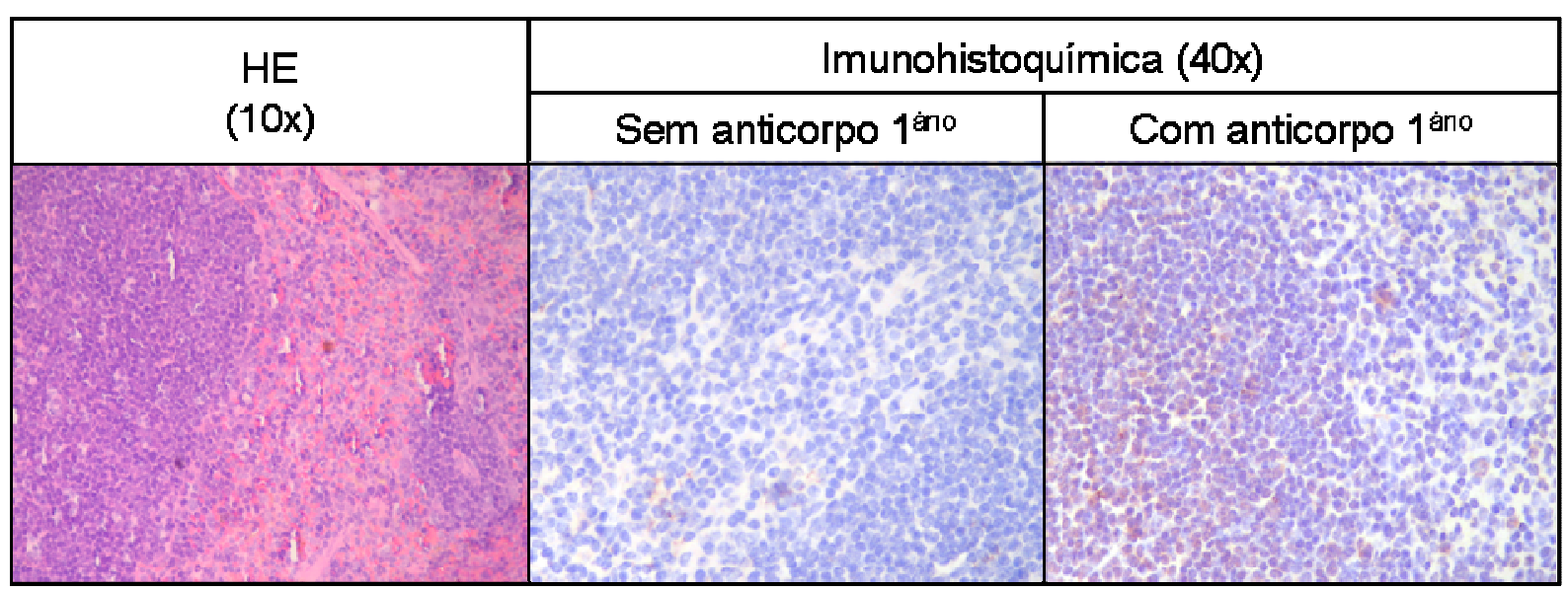




\subsection{Morfometria da proporção de polpa branca e polpa vermelha no baço}

Para determinar a proporção de polpa branca e vermelha, os preparados de baço corados pelo HE foram observados em um microscópio com ótica planacromática em pelo menos 10 campos aleatórios em aumento 10x, e digitalizados por uma câmera digital Canon Power Shot G5 (Canon Inc., Tokyo, Japan) acoplada. As imagens gravadas foram colocadas sob uma grade de 70 pontos no programa Adobe Photoshop CS2 (Adobe Systems inc., San Jose, C.A., U.S.A.), que permite a superposição de imagens, e os pontos que recaiam sobre cada polpa foram contados, sendo determinada à média de fração de volume de polpa branca e de polpa vermelha pela somatória dos achados. $O$ erro experimental estimado era menor que 0.05 para o $\mathrm{n}$ total computado. Os valores estimados de massa de cada polpa foram obtidos a partir do peso total do órgão (Cardoso et al., 1996).

\subsection{Citometria de fluxo}

Metade dos baços removidos no $4^{\circ}$, no $8^{\circ}$, e no $12^{\circ}$ dia pós-infecção (p.i.). foram dissociados mecanicamente com um pistilo em uma peneira de aço inox e suspensos em $4 \mathrm{ml}$ de PBS a $1 \%$, contendo $5 \%$ de albumina de soro bovino (BSA) e Azida 2mM (Solução A). Para retirada das hemácias presentes na suspensão, realizou-se uma centrifugação em Ficoll-Paque Plus (The General Eletric company Healthcare Bio-Sciences A.B., Fairfield, C.A., U.S.A.) por $30 \mathrm{mim}$, a $700 \mathrm{~g} \mathrm{em}$ temperatura ambiente. Após coletar o sobrenadante e a interface, a suspensão de células foi lavada 2 vezes com Solução A, em $400 \mathrm{~g} \mathrm{a} 4^{\circ} \mathrm{C}$. Ajustando a concentração de células para $10^{6} / \mathrm{ml}$ com uma câmara de hematocitometro, a suspensão foi incubada com conjugado CD34 MEC 14.7 (Santa Cruz), na concentração $1 \mu \mathrm{g}$ para cada $10^{6}$ por $30 \mathrm{mim}$, e fixada com etanol $70 \%$. A leitura foi realizada em FacsCalibur Becton Dickinson Immunocytometry Systems (Becton, Dickinson and company, Franklin Lakes, N.J., U.S.A.), com a aquisição mínima de 20.000 eventos utilizando o programa Cell Quest (Becton, Dickinson and company), e a analise feita no programa Summit $(D A K O)$, segundo o protocolo Milan-Mulhouse (Gratama et al., 1998) modificado (Figura 4). Os valores absolutos de HSPCs foram obtidos através 
da multiplicação do porcentual de HSPCs de cada órgão analisado por citometria de fluxo, pelo seu respectivo valor de massa.
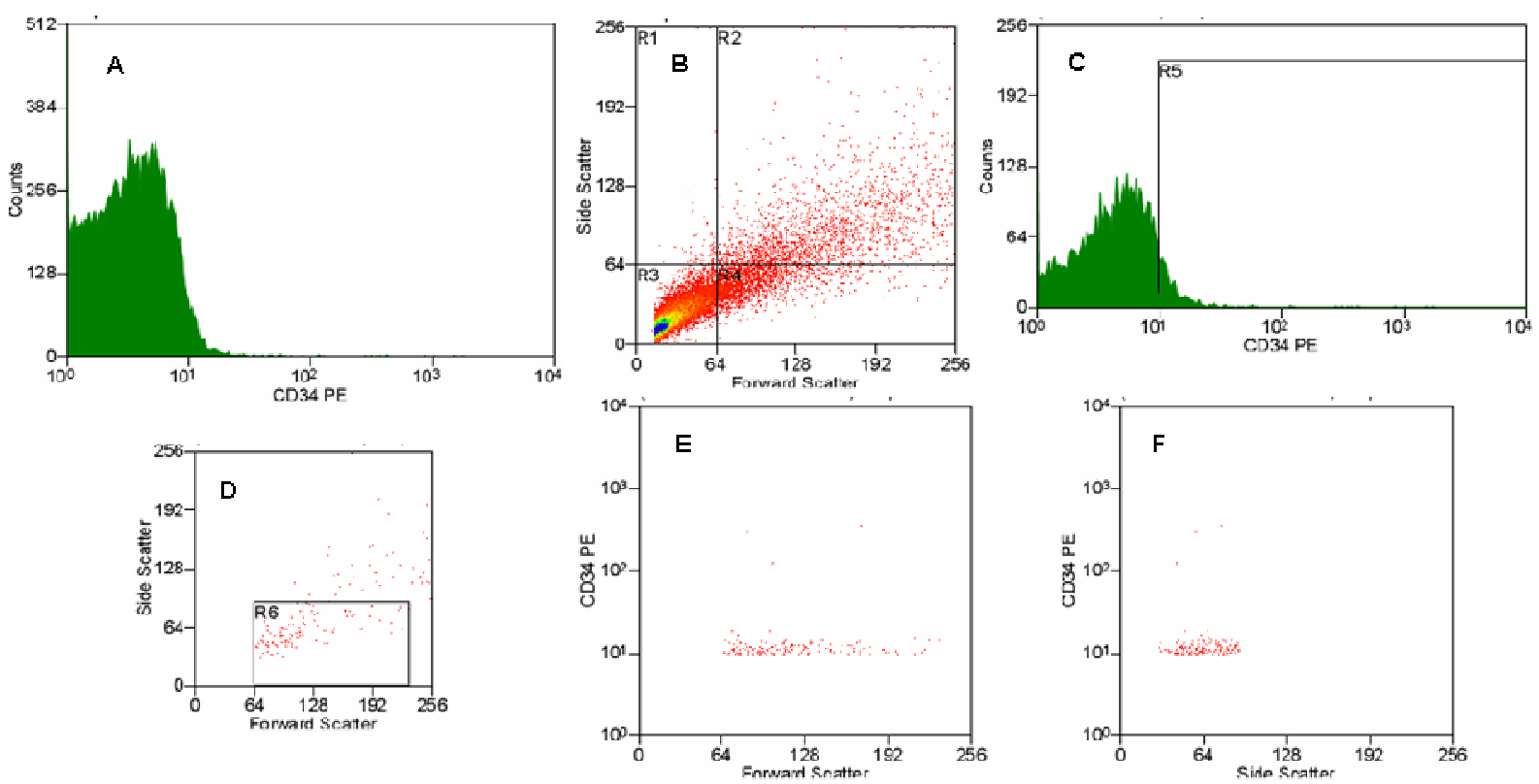

Figura 4 - Aquisição dos 20.000 eventos obtidos na citometria de fluxo pré-infecção. Realizou-se o isolamento das HSPCs segundo o protocolo Milan-mulhouse modificado: A, histograma com a fluorescência de todos os eventos; $\mathrm{B}$, dot plot FSCxSSC para isolamentos dos eventos de interrese (R2 e R4); C, histograma com fluorescência de R2 + R4 e isolamento dos eventos com fluorescência acima da primeira década do eixo; D, dot plot FSCxSSC de $\mathrm{R} 5$ e isolamento dos eventos lisos e com tamanho de médio a grande; $\mathrm{E}$ e $\mathrm{F}$, dot plot fluorescência x FSC e fluorescência x SSC, respectivamente, com as HSPCs.

\subsection{Estatística}

Os dados quantitativos foram avaliados para homogeneidade de variância e a seguir médias foram comparadas pelo teste $T$ de Student ou pelo método ANOVA com comparação entre grupos pelo método Bonferoni, usando o programa Prism 3.0 GraphPad (GraphPad Software, inc., San Diego, C.A., U.S.A.). Diferenças foram consideradas significantes quando a probabilidade de igualdade era menor que $5 \%$ $(p<0,05)$. 


\section{Resultados}

Grupos de camundongos foram infectados por $10^{6}$ hemácias parasitadas por $P$. chabaudi AJ e sua parasitemia acompanhada diariamente como descrito em Métodos. Grupos de pelo menos 03 animais foram sacrificados nos dias 4, 6, 8 e 12 após a infecção, sendo seus baços pesados, processados para histologia convencional, com determinação de proporção entre polpas, e citometria de fluxo. A evolução da parasitemia e dos caracteres esplênicos pode ser vista na figura 5. A parasitemia começa a aparecer discretamente no $1^{\circ}$ e no $2^{\circ}$ dia de infecção, e mais acentuadamente, a partir do $3^{\circ}$ dia de infecção, onde ela começa a crescer progressivamente no dias seguintes. Nesta infecção, observamos níveis de parasitemia, com no $7^{\circ}$ dia de infecção, acima de $60 \%$; contudo, a partir desse mesmo dia em diante, a parasitemia na maioria dos camundongos começa a diminuir. No $8^{\circ}$ e nos dias seguinte do período de infecção, registramos morte da maioria dos animais, tanto naqueles que permanecem com altos níveis de parasitemia como aqueles que começaram a diminuí-la. Ao termino do período de infecção, poucos animais sobrevivem a essa infecção, e mesmo esses ainda apresentam níveis elevados de parasitemia.

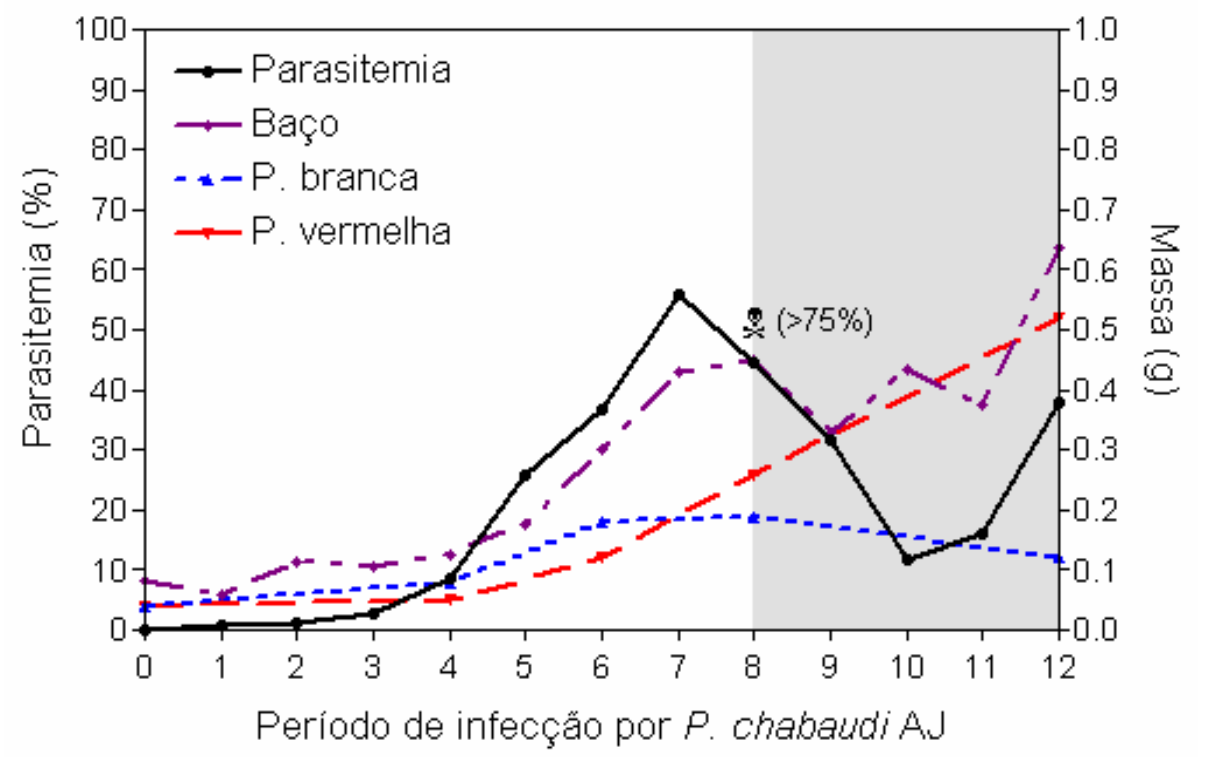

Figura 5 - Curva da variação das massas dos baços, das polpas brancas e vermelhas, e da parasitemia de camundongos $\mathrm{C} 57 \mathrm{BL} / 6 \mathrm{j}$ infectados com $P$. chabaudi AJ. A região cinza do gráfico representa o período da infecção em que se começou a registrar morte diária dos camundongos infectados. 
O aumento da massa dos baços começa a ocorrer no 4ํ dia de infecção, que é um dia após o aumento acentuado da parasitemia, e prossegue até o último dia de infecção, chegando a valores de 7 a 8 vezes maiores do que o normal (Figura 5). A massa das polpas dos baços infectados por essa cepa também começam a sofrem um aumento no $4^{\circ}$ dia de infecção, tendo as polpas brancas um maior aumento. No sexto dia de infecção, o mesmo fato também ocorre com valores maiores de massa, como os das polpas vermelhas, que chegam a ser 4 vezes maiores que o normal, e os das polpas brancas, que chegam a ser 5 vezes maiores que o normal. Contudo, a partir do 6ำ dia de infecção em diante, ocorre uma diminuição da massa das polpas brancas e um contínuo aumento da massa das polpas vermelhas, que chegam a valores 10 vezes maiores do que o normal no final do experimento.

A quantificação, por citometria de fluxo, de células CD34 ${ }^{+}$nos baços pode ser vista na figura 6 . Ocorreu no $4^{\circ}$ dia de infecção, um influxo em onda, tanto porcentual como absoluto dessa população celular, nos baços de camundongos infectados com a cepa AJ. Nos dias seguintes, observamos uma diminuição na quantidade de células CD34 ${ }^{+}$nos baços no oitavo dia de infecção, e um novo influxo em onda de células CD34 ${ }^{+}$nos baços no décimo segundo dia de infecção.

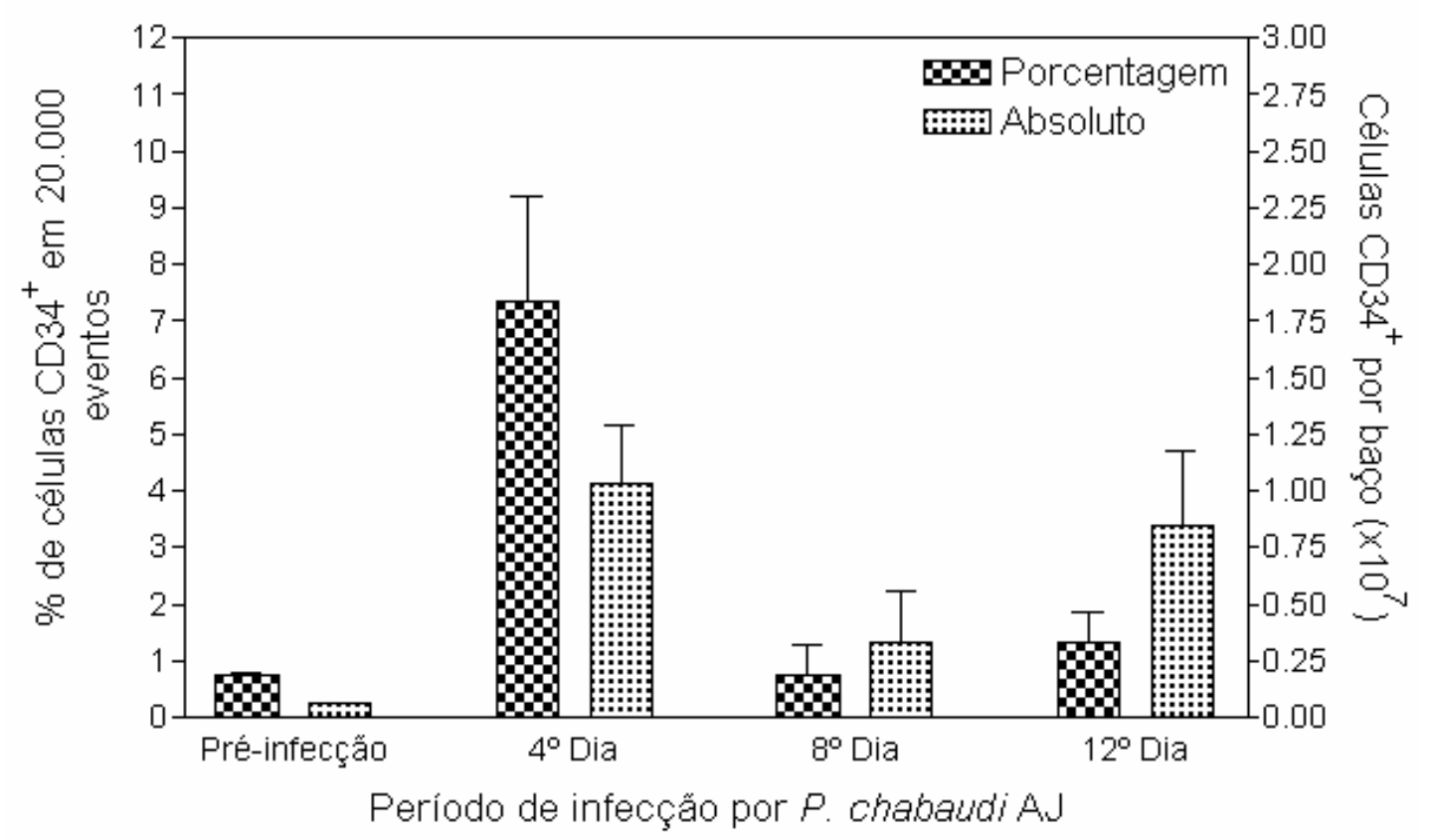

Figura 6 - Porcentagem e número absoluto de células CD34+ em baços de camundongos C57BL/6j infectados com $P$. chabaudi AJ, no $4^{\circ}, 8^{\circ}$ e $12^{\circ}$ dia p.i.. 
A organização entre as polpas esplênicas, por HE, e a distribuição das células $\mathrm{CD} 4^{+}$no tecido esplênico, por imunohistoquímica, podem ser vistas no quadro 2 . Podemos observar no $4^{\circ}$ e no $6^{\circ}$ dia p.i., os limites entre as polpas esplênicas, mas em seguida, estes limites são perdidos, indicando uma reorganização entre essas polpas. São observados focos de hematopoiese extramedular, na polpa vermelha, e centros germinativos, na polpa branca. As células CD34 ${ }^{+}$estão presentes na maior parte do tecido esplênico, mas com uma concentração preferencial na polpa vermelha. É possível também visualizar a presença de células CD34+ altamente marcadas no $4^{\circ}, 6^{\circ}$ e $12^{\circ}$ dia p.i., e no $8^{\circ}$ dia p.i., células fracamente marcadas. Isso corrobora com nossos dados de citometria de fluxo que indicam um influxo em onda dessas células no tecido esplênico no inicio e no termino do experimento, com uma possível diferenciação dessas células entre essas ondas. 
Quadro 2 - HE e imunohistoquímica de CD34 em baços de camundongos C57BL/6j infectados com

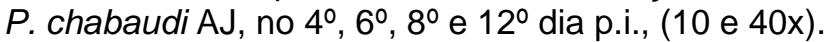

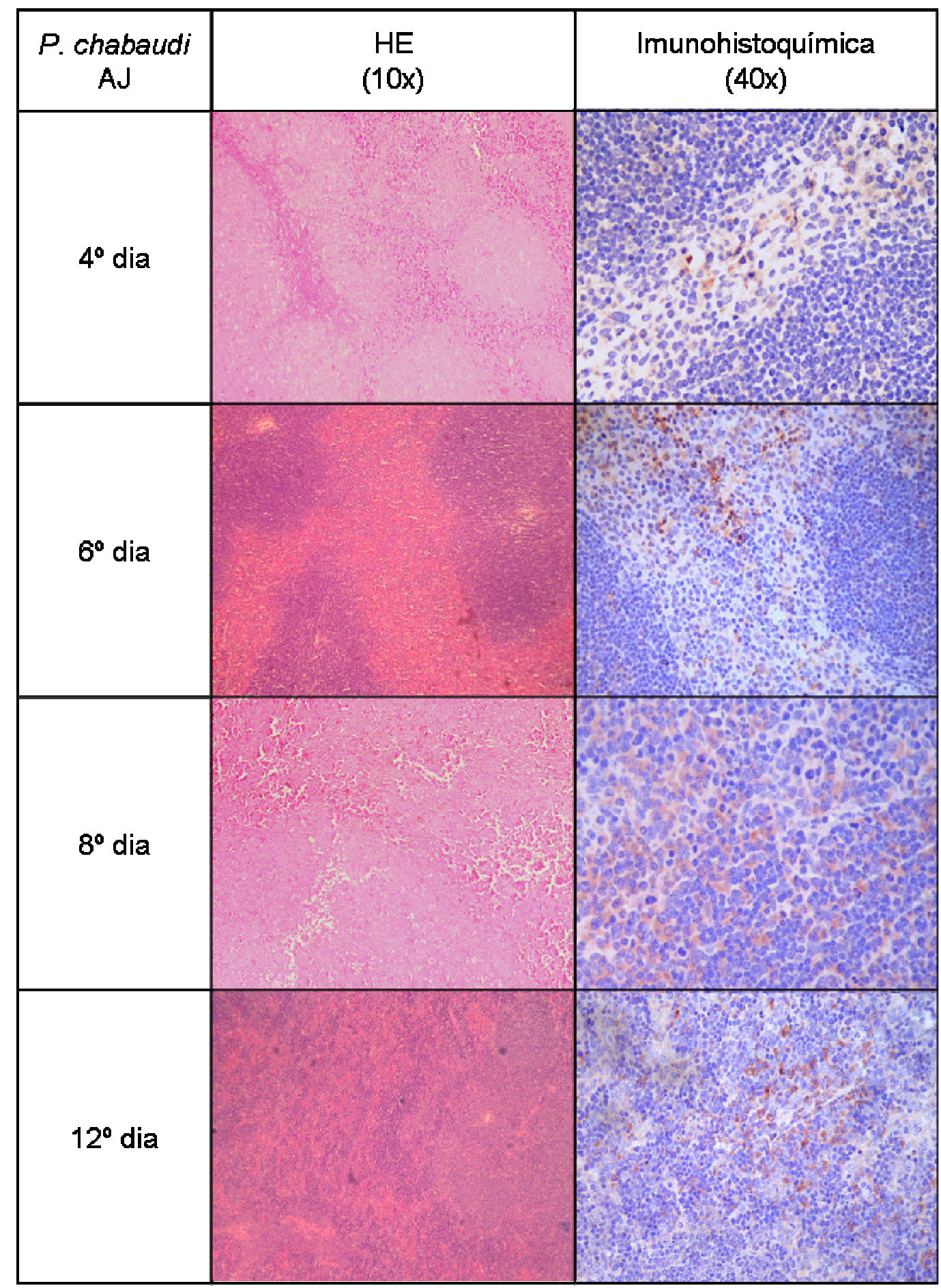


Grupos de camundongos foram infectados por $10^{6}$ hemácias parasitadas por $P$. chabaudi $\mathrm{CR}$ e sua parasitemia acompanhada diariamente como descrito em Métodos. Grupos de pelo menos 03 animais foram sacrificados nos dias 4, 6, 8 e 12 após a infecção, sendo seus baços pesados, processados para histologia convencional, com determinação de proporção entre polpas, e citometria de fluxo. A evolução da parasitemia e dos caracteres esplênicos pode ser vista na figura 7 . Semelhante à infecção anterior, a infecção por $P$. chabaudi CR apresenta a mesma cinética quanto à evolução da parasitemia, que cresce discretamente nos primeiros dias de infecção, acentuadamente a partir do $3^{\circ}$ dia de infecção, atinge um pico no $7^{0}$ dia de infecção, e cai até o termino da infecção; contudo, nesta infecção observamos níveis menos elevados de parasitemia, que não ultrapassam $50 \%$, e níveis baixos de parasitemia ao termino da infecção.

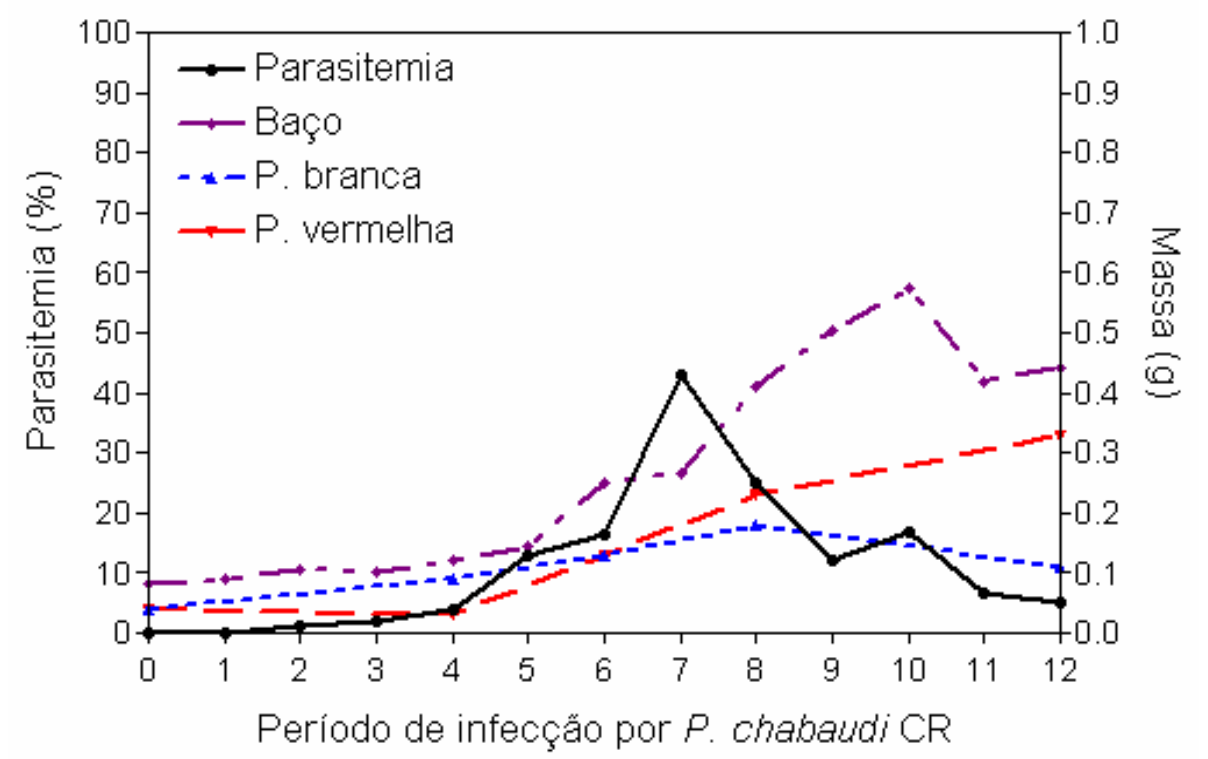

Figura 7 - Curva da variação das massas dos baços, das polpas brancas e vermelhas, e da parasitemia de camundongos $\mathrm{C} 57 \mathrm{BL} / 6 \mathrm{j}$ infectados com $P$. chabaudi $\mathrm{CR}$.

O aumento da massa dos baços, que também é semelhante à infecção anterior, começa a ocorrer no $4^{\circ}$ dia de infecção, e prossegue até o último dia de infecção, chegando a valores 7 vezes maiores do que o normal (Figura 7). A massa das polpas dos baços infectados pela cepa CR também começam a sofrem um aumento, só que as polpas brancas iniciam um aumento anterior e maior do que o das polpas vermelhas, que só aumentam a partir do $4^{\circ}$ dia e de forma menos intensa. Ao contrário da infecção pela cepa $A J$, no 6 dia de infecção pela cepa CR, as polpas vermelhas apresentam uma elevação nas suas massas e atingem valores 
muito próximos aos das polpas brancas, que são 3 vezes maiores que o normal. Seguindo o mesmo que ocorre na infecção anterior, a partir do 6으 dia de infecção em diante, ocorre uma diminuição da massa das polpas brancas e um contínuo aumento da massa das polpas vermelhas, chegando a valores 8 vezes maiores do que o normal.

A quantificação de células $\mathrm{CD} 34^{+}$, por citometria de fluxo, nos baços pode ser vista na figura 8. O influxo em onda de populações celulares $\mathrm{CD} 34^{+}$que ocorre nos baços no quarto e no décimo segundo dia de infecção pela cepa AJ também ocorre na infecção pela cepa CR. Também ocorreu no $8^{\circ}$ dia de infecção, uma diminuição na quantidade de células CD34 ${ }^{+}$nos baços.

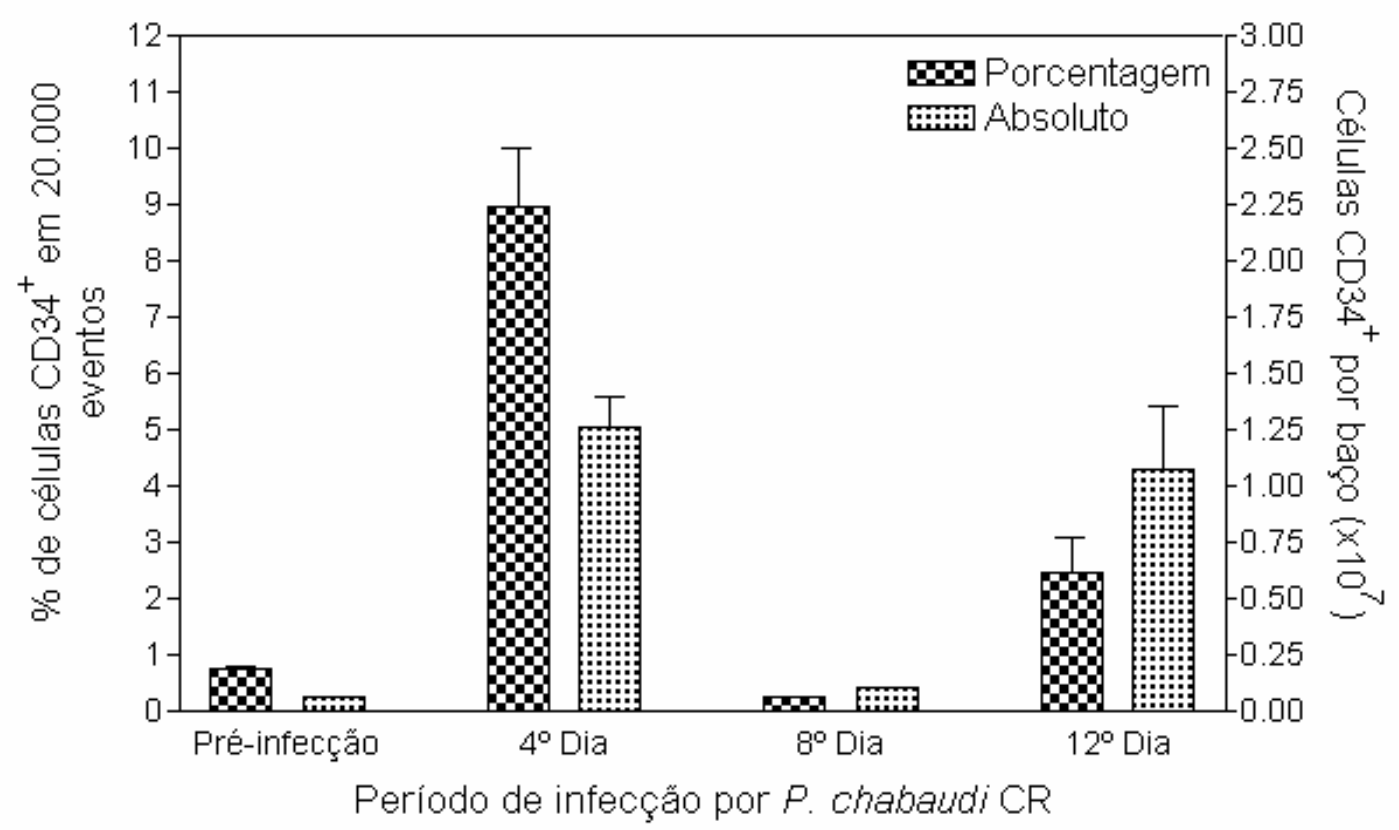

Figura 8 - Porcentagem e número absoluto de células CD34 em baços de camundongos C57BL/6j infectados com $P$. chabaudi CR, no $4^{\circ}, 8^{\circ}$ e $12^{\circ}$ dia p.i..

A proporção entre as polpas, por $\mathrm{HE}$, e a distribuição das células $\mathrm{CD}_{3} 4^{+}$no tecido esplênico, por imunohistoquímica, podem ser vistas no quadro 3 . Ao contrário do que ocorre anteriormente na infecção pela outra cepa de $P$. chabaudi, não podemos observar a perda dos limites entre as polpas esplênicas e uma reorganização entre elas. Nesta infecção também observamos focos de hematopoiese extramedular, na polpa vermelha, e centros germinativos, na polpa branca. Durante o período da infecção, como ocorre na infecção pela cepa AJ, as células $\mathrm{CD}_{3} 4^{+}$aparecem espalhadas pelo na maior parte do tecido esplênico, mas com uma concentração preferencial na polpa vermelha. Também é possível 
visualizar nesta infecção pela cepa $\mathrm{CR}$, a presença de células $\mathrm{CD} 34^{+}$altamente marcadas no $4^{\circ}, 6^{\circ}$ e $12^{\circ}$ dia p.i., e células fracamente marcadas no $8^{\circ}$ dia p.i.. Tal fato condiz com os nossos dados de citometria de fluxo que indicam um influxo no tecido esplênico em onda dessas células no inicio e no termino do experimento, com uma possível diferenciação dessas células entre essas ondas.

Quadro 3 - HE e imunohistoquímica de CD34 em baços de camundongos C57BL/6j infectados com $P$. chabaudi CR, no $4^{\circ}, 6^{\circ}, 8^{\circ}$ e $12^{\circ}$ dia p.i., (10 e $\left.40 x\right)$.

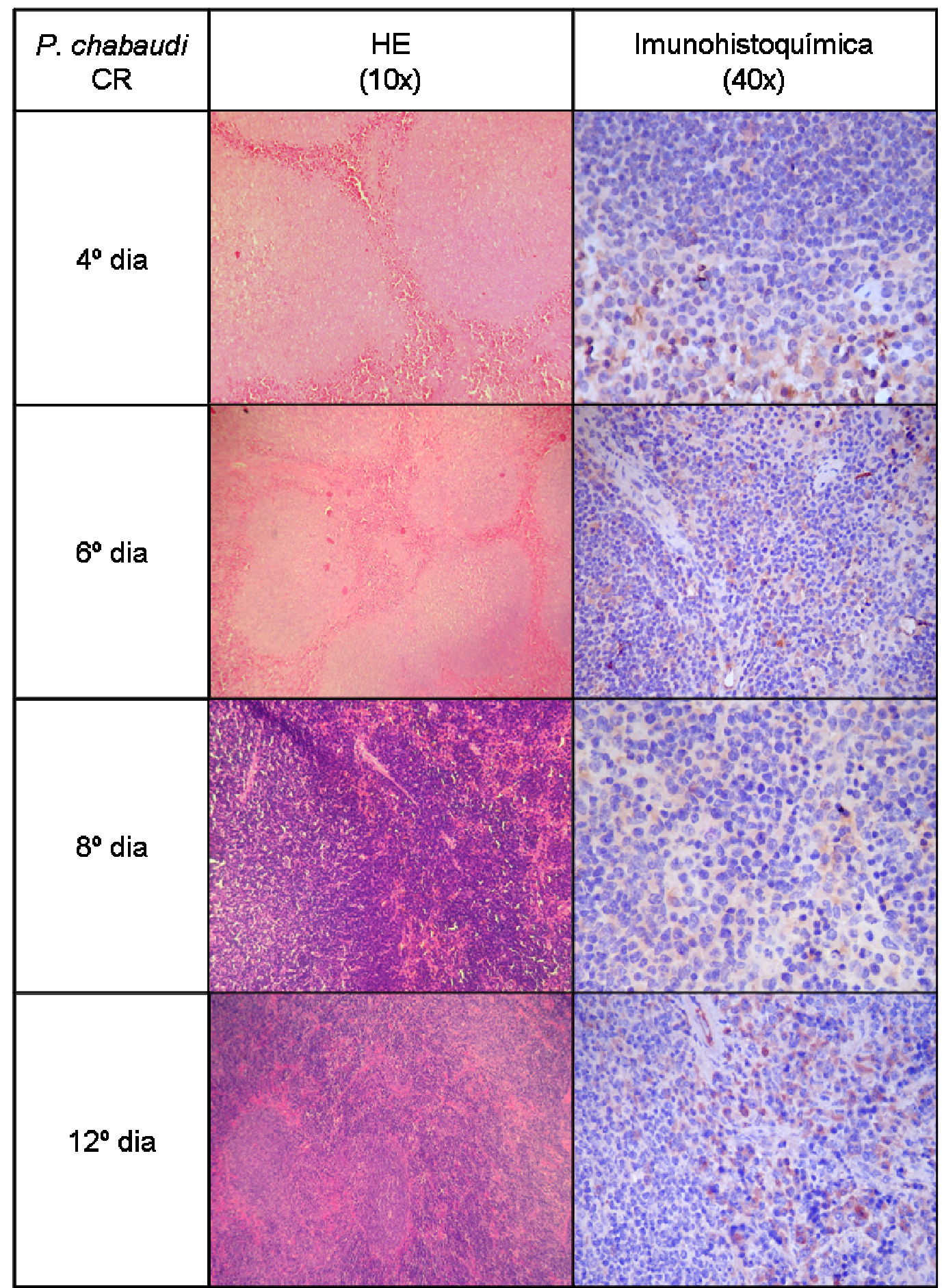


Grupos de camundongos foram infectados por $10^{6}$ hemácias parasitadas por $P$. berghei ANKA e sua parasitemia acompanhada diariamente como descrito em Métodos. Grupos de pelo menos 03 animais foram sacrificados nos dias 4, 6, 8 e 12 após a infecção, sendo seus baços pesados, processados para histologia convencional, com determinação de proporção entre polpas, e citometria de fluxo. A evolução da parasitemia e dos caracteres esplênicos pode ser vista na figura 9. Ao contrario do que ocorre nas duas cepas anteriores de $P$. chabaudi, a parasitemia na infecção por $P$. berghei ANKA só é evidente a partir do $3^{\circ}$ dia de infecção, apresenta uma evolução mais lenta e atinge níveis mais baixos do que as anteriores. A parasitemia nesta infecção atinge níveis que não ultrapassam $30 \%$, contudo, ela também não diminui ao logo do período de infecção, persistindo até o final do experimento e mostrando uma ausência de resolução no grupo infectado.

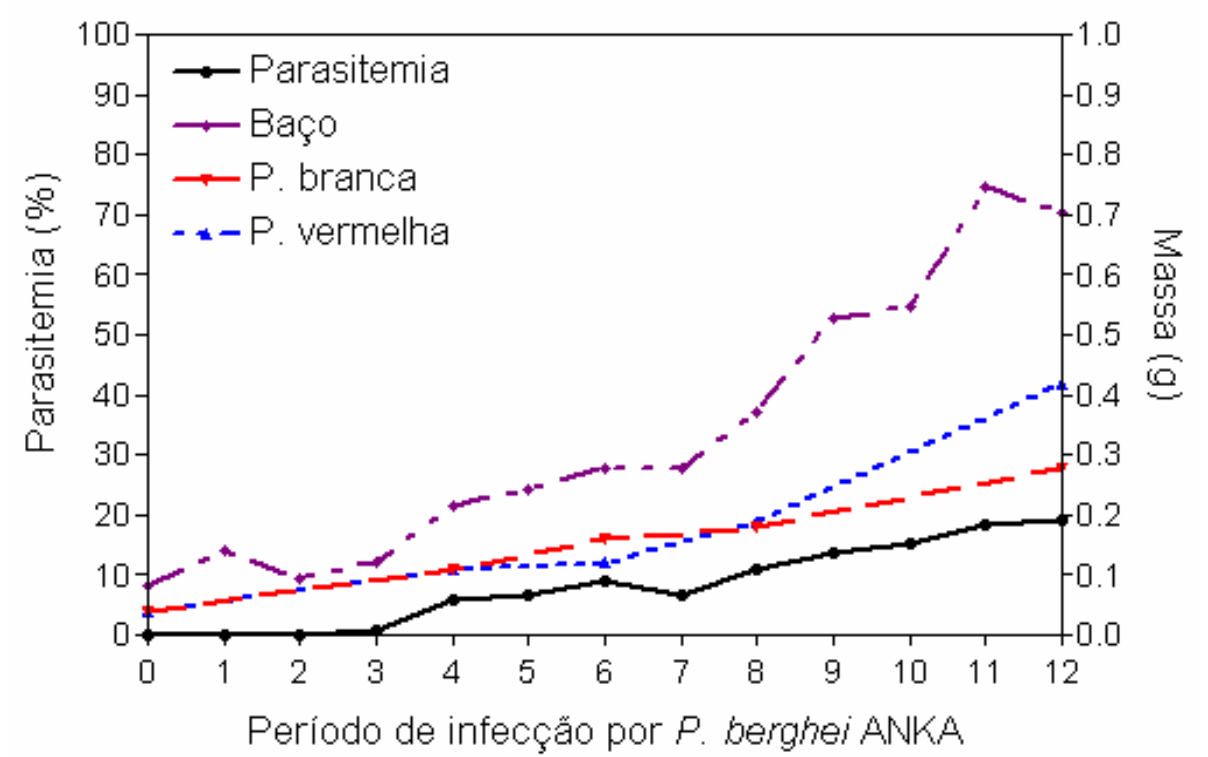

Figura 9 - Curva da variação das massas dos baços, das polpas brancas e vermelhas, e da parasitemia de camundongos C57BL/6j infectados com $P$. berghei ANKA.

A massa dos baços nessa infecção começa a aumentar um dia antes do que ocorre nas infecções anteriores, atingindo rapidamente altos valores, e segue aumentando até o final do experimento, onde chega a aumentar 9 vezes o seu valor normal (Figura 9). Ao contrario do que ocorre com as polpas esplênicas nas infecções anteriores, as polpas dos baços nessa infecção apresentam um crescimento conjunto, com um aumento primeiramente maior da polpa vermelha, entre o $4^{\circ}$ e $8^{\circ}$ dia de infecção, e um aumento maior posteriormente da polpa branca a partir do $8^{\circ}$ em diante. 
A quantificação de células $\mathrm{CD} 34^{+}$, por citometria de fluxo, nos baços pode ser vista na figura 10 . Seguindo o que ocorreu na infecção por $P$. chabaudi, o influxo em onda de populações celulares CD34+ nos baços no $4^{\circ}$ e no $12^{\circ}$ dia de infecção também ocorreu na infecção por $P$. berghei. Também ocorreu, com anteriormente, uma diminuição na quantidade de células $\mathrm{CD} 34^{+}$nos baços no $8^{\circ}$ dia de infecção.

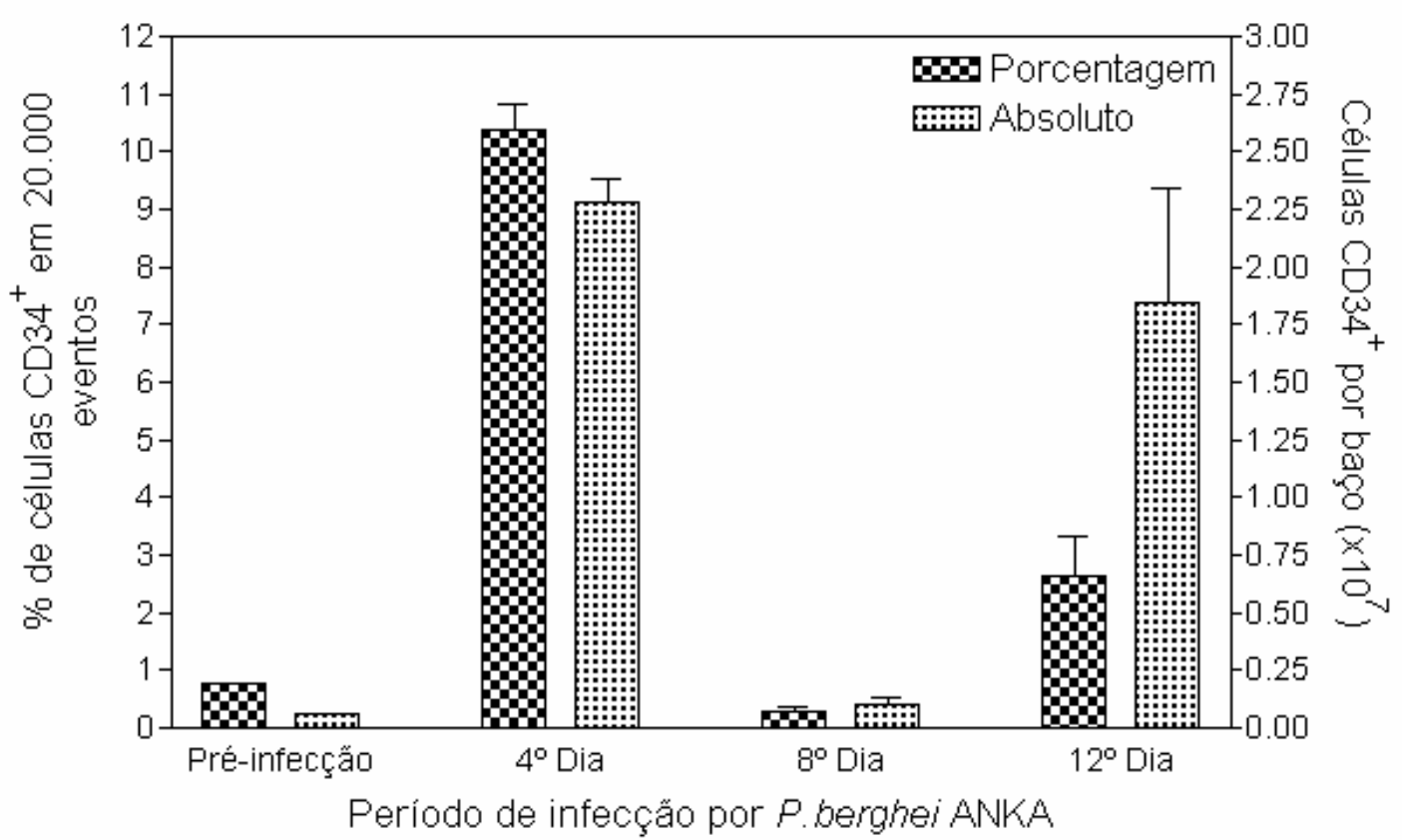

Figura 10 - Porcentagem e número absoluto de células $\mathrm{CD} 34^{+}$em baços de camundongos C57BL/6j infectados com $P$. berghei ANKA, no $4^{\circ}, 8^{\circ}$ e $12^{\circ}$ dia p.i..

A proporção entre as polpas, por $\mathrm{HE}$, e a distribuição das células $\mathrm{CD} 34^{+}$no tecido esplênico, por imunohistoquímica, podem ser vistas no quadro 4. Semelhante ao que ocorre na infecção anterior de $P$. chabaudi AJ, pode-se observar os limites entre as polpas esplênicas apenas no inicio da infecção, no $4^{\circ}$ e no $6^{\circ}$ dia p.i.; após esse período, a perda dos seus limites e a reorganização entre elas se torna visível. Como nos modelos anteriores, observados focos de hematopoiese extramedular, na polpa vermelha, e centros germinativos, na polpa branca. Semelhante ao que ocorre com as cepas anteriores de $P$. chabaudi, as células $\mathrm{CD} 34^{+}$aparecem espalhadas pelo na maior parte do tecido esplênico, mas com uma concentração preferencial na polpa vermelha. Como anteriormente, também é possível visualizar neste modelo a presença de células $\mathrm{CD} 34^{+}$altamente marcadas no $4^{\circ}, 6^{\circ}$ e $12^{\circ}$ dia p.i., e fracamente marcadas no $8^{\circ}$ dia p.i.. Isso também confirma nossos dados de citometria de fluxo que indicam um influxo no tecido esplênico em onda dessas células no inicio e no 
termino do experimento, com uma possível diferenciação dessas células entre essas ondas.

Quadro 4 - HE e imunohistoquímica de CD34 em baços de camundongos C57BL/6j infectados com $P$. berghei ANKA, no 4은 $6^{\circ}, 8^{\circ}$ e $12^{\circ}$ dia p.i., (10 e $\left.40 \mathrm{x}\right)$.

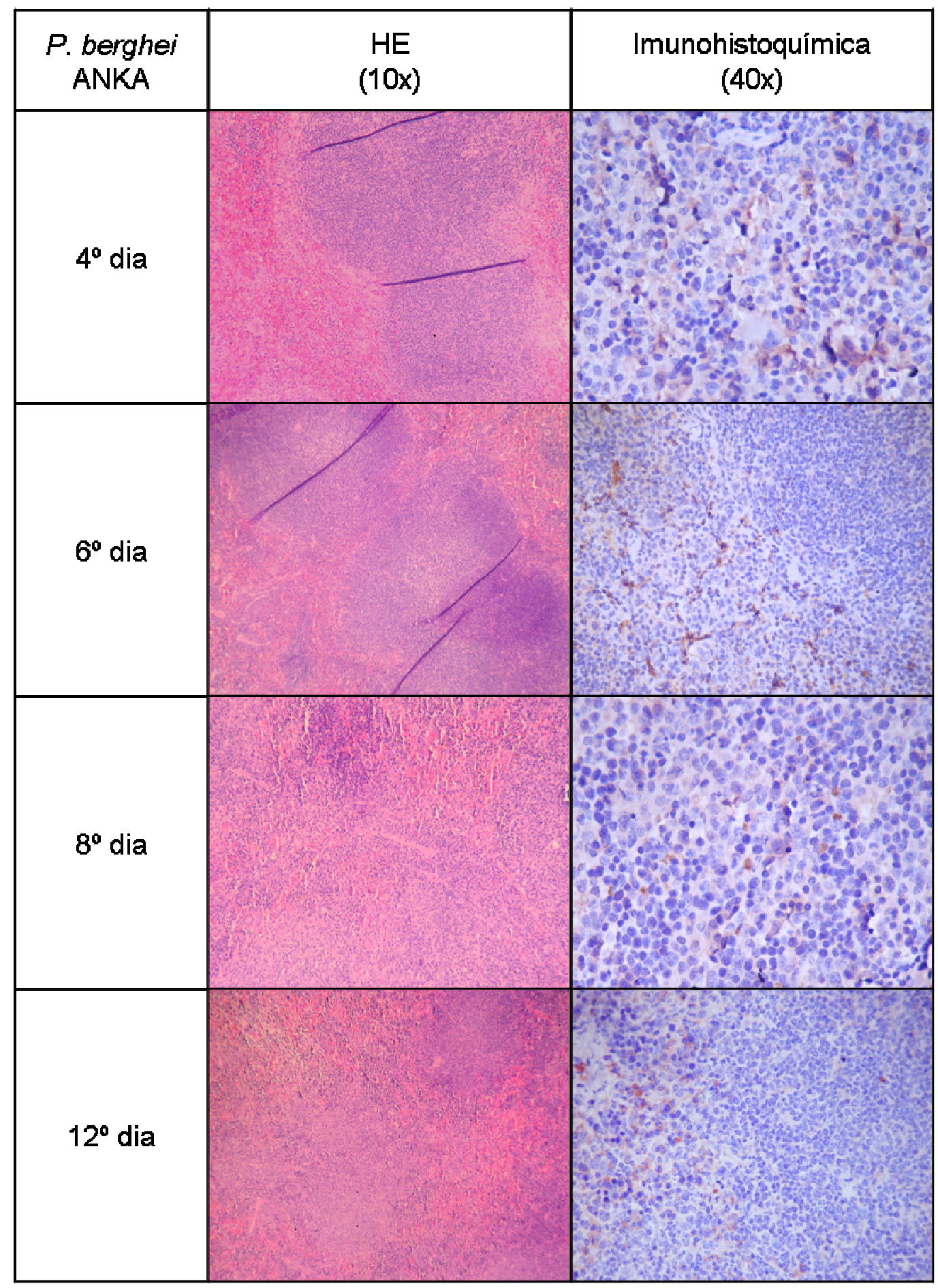


Para visualizar melhor as diferenças entre a evolução das parasitemias dos camundongos infectados com as 2 cepas de $P$. chabaudi, AJ e CR, e $P$. berghei ANKA, a figura 11 reúne a curva de parasitemias dos 3 modelos. Apesar da diferença entre os níveis de parasitemia, a evolução da mesma é semelhante tanto na infecção pela cepa $\mathrm{AJ}$, como na infecção pela cepa $\mathrm{CR}$, com um aparecimento de parasitemia no $2^{\circ}$ dia de infecção, uma ascensão até o $7^{\circ}$ dia de infecção e um declínio a partir desse mesmo dia. Já na infecção pela cepa ANKA, a parasitemia só aparece no $3^{\circ}$ dia de infecção e a sua evolução é lenta e com níveis mais baixos, além de não mostrar resolução no período de infecção. Isso nos sugere que há diferença na resposta imunológica e hematopoiética do hospedeiro durante a infecção dos três modelos utilizados.

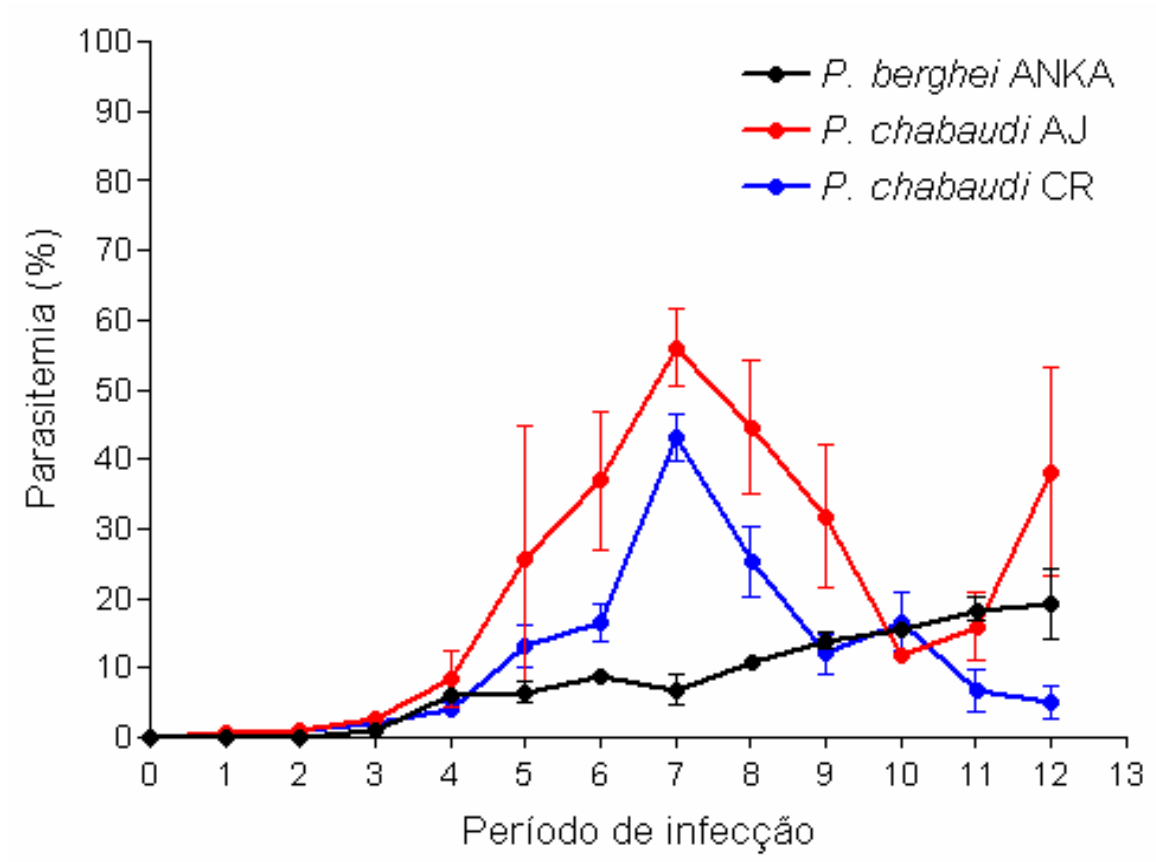

Figura 11 - Curva de parasitemia de camundongos C57BL/6j infectados com $P$. berghei ANKA e $P$. chabaudi AJ e CR. 
As diferenças entre as variações de massas dos baços nos 3 modelos podem ser melhor visualizadas na figura 12. Inicialmente, o baço dos camundongos infectados com a cepa ANKA apresentam um aumento maior do que os baços dos camundongos infectados com as cepas AJ e CR, mas entre o 6 e o 8임 os baços dos camundongos infectados com cepa AJ apresentam um aumento maior do que os outros baços. A partir do $8^{\circ}$ dia, os baços dos camundongos infectados com as cepas CR e ANKA continuam crescendo, enquanto que os baços dos camundongos infectados com a cepa AJ param de crescer. Nos camundongos infectados com a cepa CR, o crescimento do baço ocorre até o 10ำ dia de infecção, enquanto os baços dos camundongos infectados pela cepa ANKA continuam crescendo até o final do experimento. Como é visto parasitemia elevadas em camundongos infectados com a cepa AJ nos últimos dias do experimento, também ocorrem valores de massa elevados no final da infecção. Desta forma, a cinética e a evolução da infecção, que são distintas nos três modelos, e a existência características individuais de cada cepa e espécie, induzem uma congestão e uma ampliação esplênica diferente em cada infecção acompanhada durante o experimento.

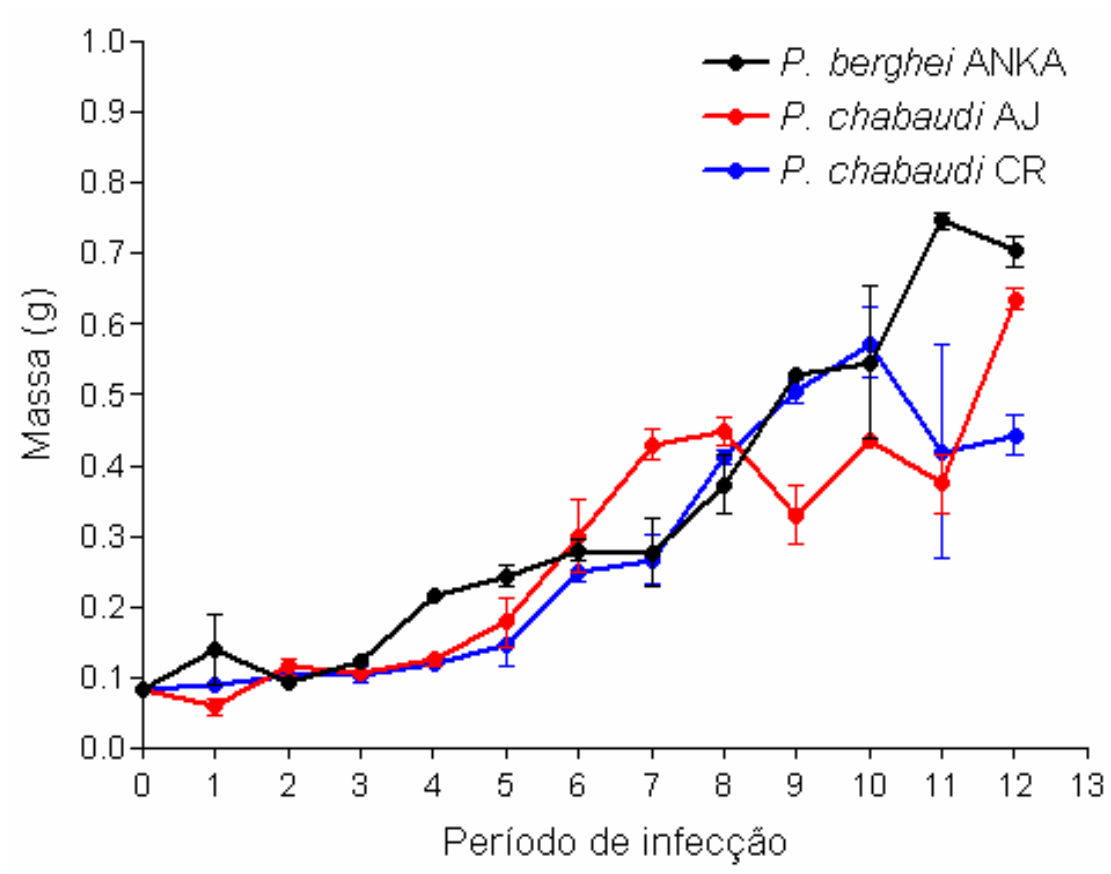

Figura 12 - Curva de variação das massas dos baços de camundongos C57BL/6j infectados com $P$. berghei ANKA e P. chabaudi AJ e CR. 
As curvas de variação de massa das polpas brancas dos baços nas três infecções estão reunidas na figura 13. Este segmento esplênico apresenta um grande aumento continuo até o $6^{\circ}$ dia da infecção, suplantando proporcionalmente a polpa vermelha neste período. Este aumento é mantido na seqüência da infecção pelo P.berghei ANKA, mas é interrompido nas cepas de P.chabaudi testadas, com decaimento absoluto e relativo. Isto sugere que a letalidade da infecção pelo P.chabaudi AJ e pelo P.berghei ANKA tem respostas imunológicas diferentes no hospedeiro.

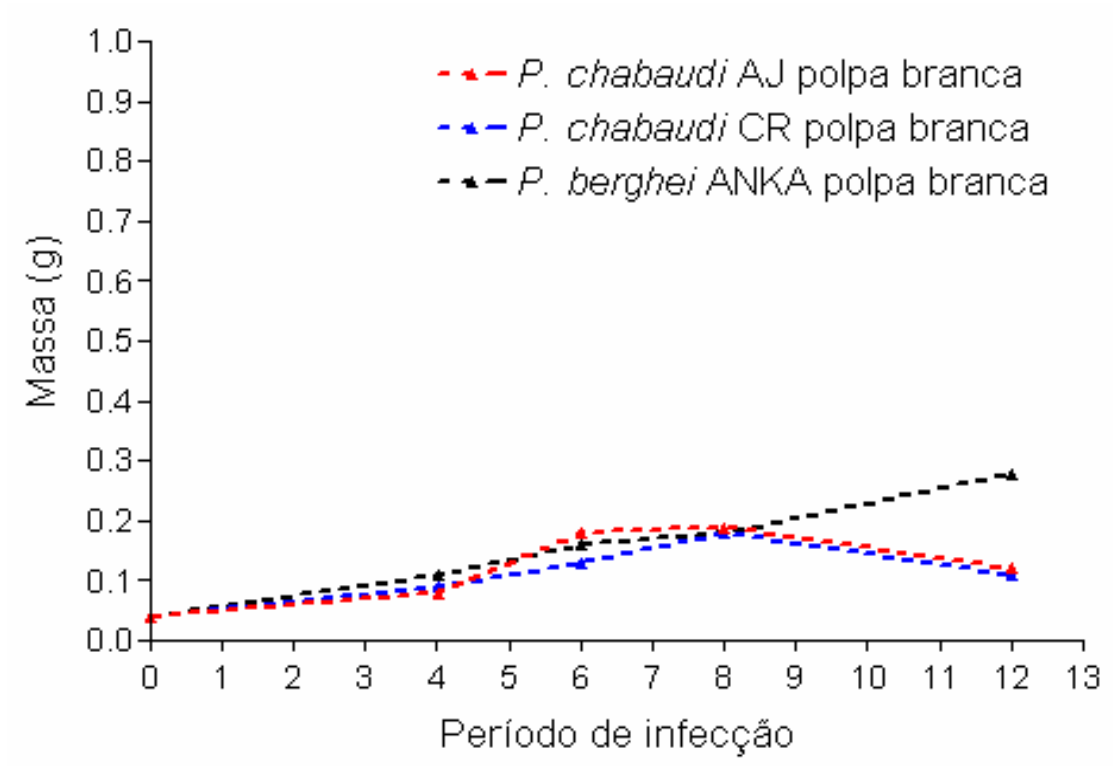

Figura 13 - Curva da variação das massas das polpas brancas de camundongos C57BL/6j infectados com P. berghei ANKA e P. chabaudi AJ e CR.

A figura 14 reúne as curvas de variação de massa das polpas vermelhas dos baços nas três infecções. As polpas vermelhas, durante a infecção pelas cepas AJ e $\mathrm{CR}$, apresentam um aumento semelhante, apesar do aumento ligeiramente maior na infecção pela cepa AJ, até o oitavo dia do experimento. Na cepa $C R$, a polpa vermelha interrompe o crescimento no período de controle da parasitemia, ausente nos outros modelos e que se correlacionam com incremento da polpa vermelha. Dessa forma, o aumento da polpa vermelha não se correlaciona com o controle mas sim com o nível de parasitemia. As polpas vermelhas na infecção pela cepa ANKA apresentam um aumento inicial maior e relação às outras infecções, mas diminui a partir do sexto dia de infecção, ficando com um aumento final maior apenas em relação com a cepa $\mathrm{CR}$. 


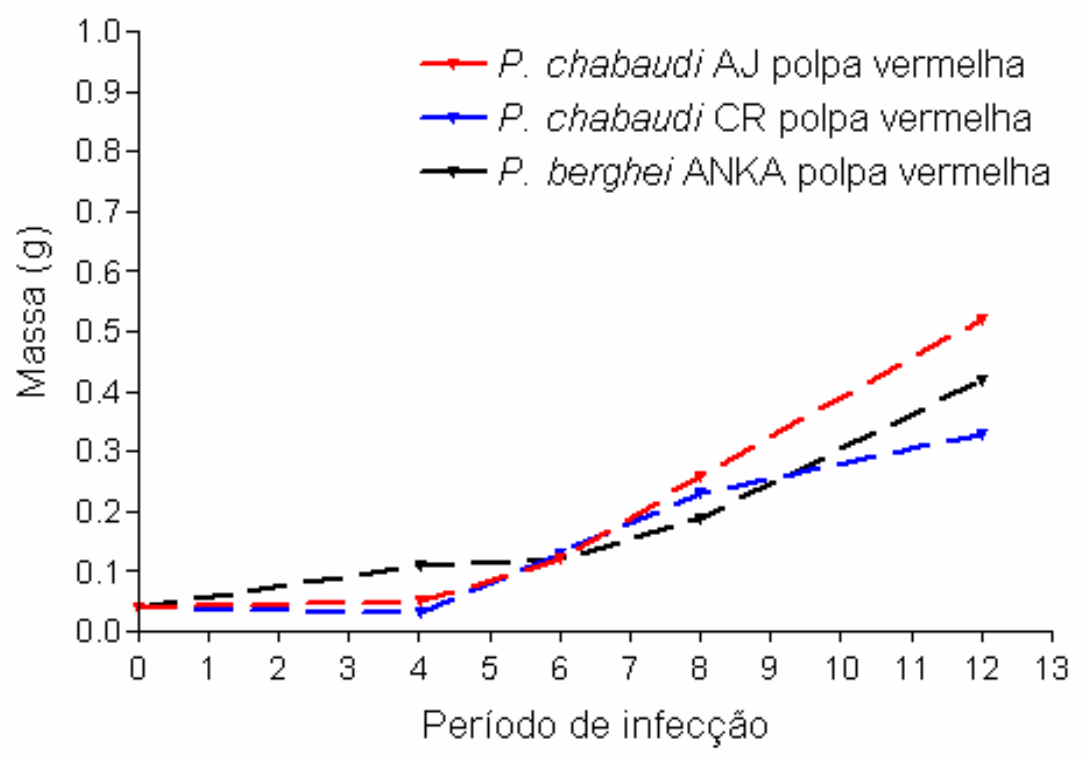

Figura 14 - Curva da variação das massas das polpas vermelhas de camundongos C57BL/6j infectados com P. berghei ANKA e P. chabaudi AJ e CR.

$\mathrm{Na}$ figura 15, podemos comparar o influxo em onda que ocorre no tecido esplênico durante o $4^{\circ}$ dia de infecção pelos três modelos. $O$ influxo, nas infecções por cepas de $P$. chabaudi, é, estatisticamente, semelhante, ao contrario do que ocorre na infecção pela cepa ANKA, que apresenta um influxo muito maior do que os que ocorrem nas outras infecções. Isso sugere que, o influxo observado pode mudar segundo as diferenças existentes nas infecções entre as espécies de plasmódio utilizadas, mas não entre as cepas de $P$. chabaudi; contudo, mesmo diferente, esse influxo parece não se relacionar com o sucesso na resolução da infecção e sobrevivência do camundongo. 


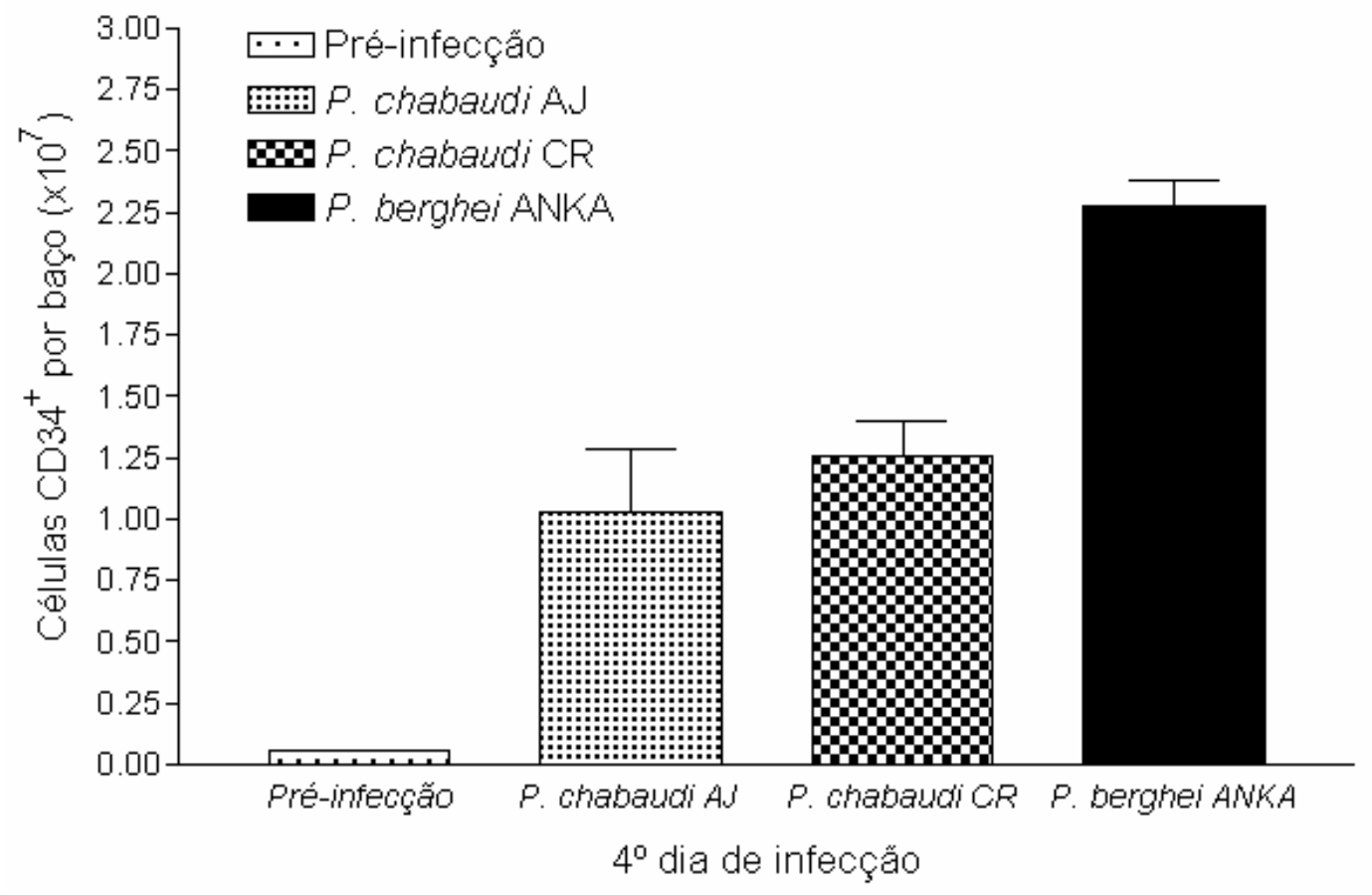

Figura 15: Número absoluto de células $\mathrm{CD} 34^{+}$nos baços de C57BL/6j camundongos infectados com $P$. berghei ANKA e $P$. chabaudi no $4^{\circ}$ dia de infecção. 


\section{Discussão}

O presente trabalho avaliou a distribuição e a quantificação das células progenitoras $\mathrm{CD}^{+} 4^{+}$na ampliação do baço durante diferentes modelos de malárias experimentais, além de analisar a curva da parasitemia nesses modelos e a evolução do peso dos baços e das suas polpas nessas infecções. As curvas de parasitemia dos camundongos infectados com as cepas AJ e CR de $P$. chabaudi apresentaram uma evolução semelhante, com uma grande ascensão inicial, um pico no $7^{0}$ dia p.i. e com uma resolução até o final do experimento; contudo, elas apresentam níveis distintos. Possivelmente, isso se deve a grande sincronia e virulência que a cepa AJ apresenta durante o seu ciclo assexuado, que leva a uma grande liberação de merozoítos na circulação devido ao rompimento de todos os esquizontes ao mesmo tempo, gerando uma grande infecção de células vermelhas e, consequentemente, uma alta parasitemia. Essa sincronia leva a uma grande ativação do sistema imune e a uma profunda anemia (Chang e Stevenson, 2004). Nos estágios terminais, com parasitemias maiores que 50\% e intensa anemia, as hemácias livres de parasitas são apenas aquelas liberadas de sítios hematopoiéticos na medula óssea e em outros locais como o baço, o que leva a intensa anemia e morte do animal. Os animais sobreviventes a esta fase da infecção apresentam parasitemia mais protraída e devem representar um grupo específico de comportamento biológico diferente, que seja por inóculo diferente ou comportamento do hospedeiro.

A curva de parasitemia nos camundongos infectados com P.berghei ANKA apresentou uma evolução mais lenta, níveis inferiores e sem resolução até o final do experimento, semelhante ao reportado na literatura (Garnica et al., 2002). Contudo, a infecção por esse plasmódio, apesar de apresentar uma parasitemia menor, não necessariamente possui uma carga antigênica menor, já este é um grande plasmódio, que apresenta uma preferência por reticulócitos, uma maior proporção de crescimento com grandes esquizontes, com quantidade maior de antígeno por célula infectada, o que pode resultar em maior oferta de antígeno para uma mesma parasitemia no P.berghei em comparação com o P.chabaudi, um plasmódio menor e com esquizontes menores. 
A evolução da ampliação do baço nos 3 modelos utilizados no experimento foi semelhante, com uma maior ampliação observada nos baço dos camundongos infectados com $P$. berghei ANKA no final da análise ao $12^{\circ}$ dia de infecção. Essa maior ampliação pode estar relacionada com uma maior congestão que esses baços sofrem durante essa infecção. Essa espécie de plasmódio causa nas células vermelhas parasitadas hipertrofia e isso pode dificultar a passagem delas pelas IES (Killick-Kendríck, 1974). Comparativamente, a cepa AJ foi a que causou maior aumento relativo do baço nas fases mais agudas, evidente ao $7^{\circ}$ dia de infecção, antes da ocorrência da mortalidade.

A evolução das polpas esplênicas também se apresenta diferente nos três modelos. Os baços dos camundongos infectados com $P$. chabaudi AJ apresentam no final do experimento uma polpa vermelha maior que as outras polpas vermelhas dos outros modelos, que pode estar ligada aos altos níveis de parasitemia que essa infecção apresenta. Isto pode estar relacionado ao intenso envolvimento do baço na reposição de células vermelhas do sangue. Este fato já havia sido relatado em modelos experimentais semelhantes, mostrando um envolvimento hematopoiético do baço na reposição de células vermelhas do sangue, como tem sido relatado em casos humanos de mielodisplasia (Barosi et al., 2004). Nos outros modelos este fenômeno parece estar relacionado a eventos mais tardios da infecção, o que pode estar ocorrendo nos animais sobreviventes da cepa AJ e nos demais modelos. Interessante notar no que no modelo da cepa $\mathrm{CR}$, esta evolução para hematopoiese é menos evidente, já que ocorre o controle da infecção. Ainda na infecção por $P$. berghei ANKA, o maior aumento da polpa vermelha sofre no inicio dessa infecção, ao $4^{\circ}$ dia, pode estar ligado a maior deformidade que esse parasita causa a célula infectada somado a grande habilidade que a rede de filtração, que esta inserida nessa polpa, possui para capturar células vermelhas aberrantes (Groom et al., 1991).

A polpa branca dos baços dos camundongos infectados com $P$. berghei ANKA apresenta, ao longo do experimento, uma ampliação constante não encontrada nos outros modelos, que pode estar ligada à alta carga antigênica que esse plasmódio pode oferecer por parasita e, consequentemente, uma maior estimulação e ampliação do tecido linfóide do baço. Este fato parece mostrar que nos modelos de Plasmodium chabaudi, a ampliação da polpa branca deve ser em 
algum momento eficiente ou interrompido, resultando na morte no modelo AJ e no controle no modelo CR.

Observando-se a histologia convencional dos baços durante as infecções, fica claro que os estudos quantitativos de polpas refletem-se na histologia, mostrando uma intensa hematopoiese extramedular em todas as modelos e uma intensa ativação também da polpa branca. Esta ativação já é evidente no 4ํ dia, mas evolui com perda dos limites exceto no modelo por cepa $C R$, onde a estrutura esplênica parece mais preservada. A polpa branca apresenta os sinais característicos de ativação, com folículos com centros germinativos, com em qualquer ativação imunológica (Janeway et al., 2005).

A imunohistoquímica das células $\mathrm{CD} 4^{+}$mostra um comportamento mais complexo, com dois tipos de envolvimento. Na polpa branca, as células CD34 ${ }^{+}$ podem ser vistas ocasionalmente dispersas dentro dos folículos, com alguma marcação mais intensa nos animais controles, similar ao descrito na literatura (Pusztaszer et al., 2006). Não podemos dizer que não houve influxo, pois para isso precisaríamos de células marcadas infundidas no camundongo. Só é possível dizer que o número delas não se alterou significativamente, e se houve influxo, foi compensado pela taxa de efluxo e/ou morte desta população.

$\mathrm{Na}$ polpa vermelha os fenômenos são muito mais intensos. Não havia marcação nos controles sadios e já no 4ํ dia há uma intensa marcação de células na polpa vermelha, tanto de células isoladas como do estroma vascular.

No decorrer da infecção, em todos os modelos, é possível observar inicialmente por imunohistoquímica, em especial na polpa vermelha e na zona marginal, uma intensa marcação de $C D 34^{+}$em várias células que possivelmente são oriundas do processo de mobilização que ocorre na medula óssea, que pode ser explicado pelo aumento na expressão de CXCL12 no tecido esplênico durante uma infecção por P. chabaudi CR e P. berghei ANKA (Garnica et al., 2002; Garnica et al., 2003) que é uma quimiocina responsável pela migração e adesão de HSPCs em nichos hematopoieticos.

Conforme ocorre a ampliação, a polpa vermelha passa a apresentar focos hematopoiéticos extramedulares, e a marcação de $\mathrm{CD} 4^{+}$nas células fusiformes aparece mais fraca, sugerindo uma grande diferenciação de células progenitoras em outras linhagens celulares que participam do processo inicial de ampliação e no 
processo final de clareamento, o que leva a uma baixa marcação CD34 ${ }^{+}$. Ao termino do experimento, é possível observar novamente uma intensa marcação de CD34 ${ }^{+}$ em células da polpa vermelha e da zona marginal, indicando um novo influxo, que se supõe ser novamente da medula óssea.

Os eventos imunohistoquímicos foram confirmados por citometria de fluxo, onde se observa um influxo em onda de células CD34+ livres, no início da infecção malárica em todos os modelos. Utilizando o protocolo Milan-Mulhouse (Gratama et al., 1998) modificado que permite identificar somente as células HSPCs CD34+, pode-se observar no início da infecção, que é o momento onde o baço inicia sua ampliação, um grande influxo de células com intensa marcação de CD34 ${ }^{+}$. Posteriormente, durante o pico da parasitemia, observa-se um baixo número de células $\mathrm{CD} 4^{+}$com essa intensa marcação, indicando uma possível diferenciação das HSPCs em outras linhagens, tanto eritropoiéticas como vasculares, já que a marcação da polpa vermelha na imunohistoquímica assim sugere. No termino do experimento, observamos novamente um grande número de células com intensa marcação de CD34 ${ }^{+}$, que pode indicar um novo influxo de HSPCs no baço.

Entre as cepas de P.chabaudi, não se observa diferença na quantidade do influxo de células $\mathrm{CD}^{+} 4^{+}$no baço durante o $4^{\circ}$ dia p.i., indicando que o influxo dessas células não está relacionado com a resolução da infecção, mas sim com a ampliação esplênica e hematopoiética. Na infecção por $P$. berghei ANKA, é possível identificar, no $4^{\circ}$ dia p.i., um influxo maior de células $C D 34^{+}$do que os que ocorrem nos modelos de $P$. chabaudi, porém não se mostra associado ao controle da infecção. Uma possível explicação para esse maior influxo que ocorre na infecção por $P$. berghei ANKA, é que esse modelo provavelmente induz uma congestão mais intensa no baço, devido às grandes alterações que esse parasita causa a célula infectada (Killick-Kendríck, 1974), e isso gera um maior stress para o órgão, que por sua vez, induz um maior influxo para tentar atender essa maior congestão.

Estes achados histológicos e citométricos são específicos e não encontramos descrições na literatura de comportamento das células $\mathrm{CD} 4^{+} \mathrm{em}$ malária, quer humana ou experimental. Existe porém algumas descrições de células progenitoras, baseados em ensaios de formação de colônias, sem identificação pelo marcador utilizado. Nestes ensaios, foi encontrada também uma onda de produção de células progenitoras relacionada ao $4^{0}$ dia da infecção para decair a seguir, em malária por 
P.berghei (Asami et al., 1992). Os mesmos autores, utilizando animais deficientes em células progenitoras, mostraram maior mortalidade de animais deficientes, sem aumento do baço, mostrando que a hematopoiese esplênica era importante (Asami et al., 1991).

Em modelos semelhantes, também foi demonstrada a importância da eritropoiese extramedular no baço, com recrutamento de células medulares. Estes autores sugeriam que 0 defeito na capacidade de implantar uma eritropoiese extramedular esplênica estava diretamente relacionado à mortalidade, já que os níveis de eritropoetina e outros fatores hematopoiéticos eram semelhantes (Villevall et al., 1990). Isto explica algumas alterações medulares encontrados em pacientes com malária e anemia, onde há uma interrupção de maturação da eritropoiese, apesar de estímulo adequado por eritropoetina (Abdalla e Wickramasinghe,1988). Estas alterações foram atribuídas a fatores solúveis no soro de pacientes tailandeses (Jootar et al., 1993). Este complexo defeito de eritropoiese foi atribuído a uma interação de citocinas inflamatórias com as células eritropoiéticas. A interleucina-12, um potente estimulador da produção de IFN e TNF produzido por células NK foi estudado em modelos experimentais e mostrou uma relação inversa com a diseritropoese (Mohan e Stevenson, 1998). Outra citocina inflamatória, o TNF, foi implicado por vários autores como causa da diseritropoise na malária, como adequadamente revisto na literatura (Odeh, 2001), mas recentemente não foi possível implicá-lo como causa de anemia e sim apenas acompanhando o processo, tanto em malária humana (Casals-Pascual et al., 2006) como em modelos experimentais (Hernandez-Valladares et al., 2006). Outro aspecto importante a destacar na anemia seria a inflamação intramedular, que é importante no dano mediado pela radiação ionizante (Lorimore et al., 2001), já que existem relatos tanto de agressões mediadas por radicais inflamatórios, como o óxido nítrico (Garnica et al., 2003), fatores produzidos localmente por macrófagos (McDevitt et al., 2006) ou mesmo produtos de degradação da hemoglobina, como a hemozoína (HernandezValladares et al., 2006).

Nosso trabalho estudou a participação das células CD34+ na ampliação do baço, êste um processo crucial para o controle da parasitemia. Entretanto, não há um bloqueio de infiltração dessas células nos modelos letais, que mostram o mesmo padrão no baço que o modelo não letal. Estes dados sugerem que outros 
mecanismos, pouco relacionados com as células $\mathrm{CD}_{34^{+}}$, estão envolvidos na indução de morte ou cura nestas infecções. Trabalhos descrevem o infiltrado de células CD11c (Ing et al., 2006), um típico progenitor linfóide do baço, que poderia estar relacionado com a migração induzida pelo CXCL12, encontrada por outros autores (Garnica et al., 2002). Esta quimiocina funcionaria tanto na atração de HSPCs e progenitoras endoteliais para o baço, como também para precursores linfóides esplênicos, já que sua administração em modelos experimentais induz

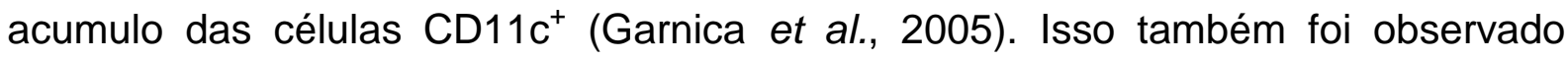
isoladamente na malária por P. chabaudi AS por outros autores (Leisewitz et al., 2004), mas não podemos excluir um efeito recíproco entre essas células precursoras. Um aumento de células $\mathrm{CD} 34^{+}$no tecido esplênico pode indicar um aumento na hematopoiese que pode ajudar na resolução da infecção malárica, especialmente se este aumento representar também um aumento e/ou ativação adequada das populações celulares envolvidas na resposta imune. Este aumento poderia ser auxiliado por estas células em diferentes mecanismos, já que também são progenitoras de células da resposta imune ou hospedeiras em processos de integração e diferenciação (Kobari et al., 2006).

No nosso modelo letal, o aumento isolado de células CD34 $^{+}$não foi relacionado com o sucesso no controle da infecção por malária e, portanto, não podemos atribuir um papel essencial destas células no controle da doença. Uma possibilidade é que essas células estejam relacionadas apenas na recomposição dos eritrócitos destruídos, mas não sabemos se elas foram ativadas para diferenciação e/ou divisão, nem se entraram em quiescência, e nem se entraram em apoptose, apesar de não haver indícios claros de presença de apoptose nas lâminas. Contudo, acreditamos nessa possibilidade até que nos mostrem total paralisação das atividades de mitose/diferenciação destas células ou apoptose.

O quadro atual mostra alguns aspectos da complexa e específica relação da malária com o seu hospedeiro e da dificuldade de estudar modelos de interações celulares complexos, como a hematopoiese extramedular. Apenas alguns aspectos podem ser analisados em cada evento e muitas teorias altamente atraentes por estudos isolados mostraram-se pouco consistentes. Uma avaliação crítica e um estudo constante, principalmente na elucidação do tráfego da população hematopoiética primitiva, de modo a determinar o momento e a intensidade de cada 
seqüência de eventos imunológicos disparados pela diferenciação celular de progenitores a efetoras, são essenciais para um maior entendimento desse processo. Esperamos assim ter contribuído com mais um dado para a compreensão futura desta complexa interação. 


\section{Conclusões}

\subsection{Conclusão geral}

Há um influxo em ondas de células CD34+ no baço no $4^{\circ}$ dia e $12^{\circ}$ dia da infecção por P.chabaudi e por $P$. berghei, independente da letalidade da espécie ou cepa infectante, tanto por citometria de fluxo quantitativa ou imunohistoquímica, interrompido por uma aparente diferenciação. Em nossos dados, o aumento isolado de células CD34+ não está relacionado com sucesso no controle da infecção por malária.

\subsection{Conclusões especificas}

A infecção pela cepa AJ de $P$. chabaudi possui uma rápida ascensão da parasitemia, com altos níveis, e uma grande ampliação final da polpa vermelha.

Nesta mesma infecção, o influxo em onda de células CD34 ${ }^{+}$nos tecidos esplênicos dos camundongos infectados está presente no $4^{\circ}$ e novamente no $12^{\circ}$ p.i..

A ampliação esplênica, durante essa infecção, reorganiza o arranjo e a estrutura das polpas do baço na ascensão da parasitemia. As células CD34 ${ }^{+}$estão presentes em todo o tecido esplênico, mas com maior concentração na polpa vermelha.

A infecção pela cepa $\mathrm{CR}$ de $P$. chabaudi também possui uma rápida ascensão da parasitemia e uma ampliação final da polpa vermelha, só que níveis mais baixos do que ocorre na infecção pela cepa AJ.

O influxo em onda de células CD34 ${ }^{+}$também ocorre nos tecidos esplênicos dos camundongos infectados por essa cepa, durante o $4^{\circ}$ e novamente no $12^{\circ}$ p.i.. 
A ampliação esplênica, na infecção pela cepa $C R$, reorganiza o arranjo e a estrutura das polpas do baço na fase de declínio da parasitemia. As células CD34 estão presentes em todo o tecido esplênico, mas com maior concentração na polpa vermelha.

Na infecção por $P$. berghei ANKA, a parasitemia, que apresenta níveis baixos, possui uma evolução lenta e persistente, e a polpa branca possui um grande aumento final.

O mesmo influxo em onda de células CD34+ também ocorre, durante o $4^{\circ} \stackrel{\mathrm{e}}{ }$ $12^{\circ}$ p.i., nos tecidos esplênicos dos camundongos infectados por $P$. berghei ANKA, só que com valores superiores aos que ocorrem nas infecções por $P$. chabaudi.

Ainda nesta infecção, a ampliação esplênica reorganiza o arranjo e a estrutura das polpas do baço também na ascensão da parasitemia. As células ${\mathrm{CD} 34^{+}}^{+}$estão presentes em todo o tecido esplênico, mas com maior concentração na polpa vermelha.

A evolução da parasitemia, nos três modelos estudados, esta de acordo com o que está descrito na literatura.

A congestão causa uma hipertrofia no baço e nas sua estruturas, que se reorganizam.para realizar o clareamento sangüíneo.

O aumento da polpa vermelha não se correlaciona com o controle mas sim com o nível de parasitemia.

A maior esplenomegalia causada pelo P.berghei ANKA está relacionada com a hipertrofia que este parasita causa no eritrócito.

A infecção pelo P.chabaudi AJ e pelo P.berghei ANKA tem respostas imunológicas diferentes no hospedeiro e causam morte por razões distintas. 
O influxo observado pode mudar segundo as diferenças existentes nas infecções entre as espécies de plasmódio utilizadas, mas não entre as cepas de $P$. chabaudi. 


\section{Referências Bibliográficas}

Abdalla SH, Wickramasinghe SN. A study of erythroid progenitor cells in the bone marrow of Gambian children with falciparum malaria. Clin Lab Haematol. 1988; 10(1):33-40.

Alves HJ, Weidanz W, Weiss L. The spleen in murine Plasmodium chabaudi adami malaria: stromal cells, T lymphocytes, and hematopoiesis. Am J Trop Med Hyg. 1996 Oct; 55(4):370-8.

de Andrade Junior HF, Laurenti MD, Goto H, Duarte MI, Corbett CE. Experimental malaria: contamination of strains and experimental animals by Eperythrozoon coccoides. Rev Inst Med Trop Sao Paulo. 1986 Jul-Aug; 28(4):246-52.

Andrade Junior HF, Corbett CE, Laurenti MD, Duarte MI. Comparative and sequential histopathology of Plasmodium chabaudi-infected Balb/c mice. Braz J Med Biol Res. 1991; 24(12):1209-18.

Asami M, Abe T, Owhashi M, Nawa Y. Appearance of adherent cells suppressive to erythropoiesis during an early stage of Plasmodium berghei infection in mice. Southeast Asian J Trop Med Public Health. 1992 Jun; 23(2):184-8.

Asami M, Owhashi M, Abe T, Nawa Y. Susceptibility of multipotent haemopoietic stem cell deficient W/Wv mice to Plasmodium berghei-infection. Immunol. Cell Biol. 1991 Oct; 69 (Pt 5):355-60.

Bach O, Baier M, Pullwitt A, Fosiko N, Chagaluka G, Kalima M, Pfister W, Straube E, Molyneux M. Falciparum malaria after splenectomy: a prospective controlled study of 33 previously splenectomized Malawian adults. Trans R Soc Trop Med Hyg. 2005 Nov; 99(11):861-7.

Balmer P, Alexander J, Phillips RS. Protective immunity to erythrocytic Plasmodium chabaudi AS infection involves IFNgamma-mediated responses and a cellular infiltrate to the liver. Parasitology. 2000 Nov; 121(Pt 5):473-82.

Barosi G, Rosti V, Massa M, Viarengo GL, Pecci A, Necchi V, Ramaioli I, Campanelli $R$, Marchetti $M$, Bazzan M, Magrini U. Spleen neoangiogenesis in patients with myelofibrosis with myeloid metaplasia. Br J Haematol. 2004 Mar; 124(5):618-25. 
Barton SG, McNagny K. Beyond Mere Markers: Functions for CD34 Family of Sialomucins in Hematopoieis. Immunol Res. 2006; 34/1:13-32.

Belnoue E, Costa FT, Frankenberg T, Vigario AM, Voza T, Leroy N, Rodrigues MM, Landau I, Snounou G, Renia L. Protective T cell immunity against malaria liver stage after vaccination with live sporozoites under chloroquine treatment. J Immunol. 2004 Feb 15; 172(4):2487-95.

Bertoli M, Moitinho MR. Malária no Estado do Paraná, Brasil. Rev. Soc Bras Med Trop. 2001 jan./fev; 34(1):43-47.

Brendolan A, Rosado MM, Carsetti R, Selleri L, Dear TN. Development and function of the mammalian spleen. Bioessays. 2007 Feb; 29(2):166-77.

Camargo LM, dal Colletto GM, Ferreira MU, Gurgel Sde M, Escobar AL, Marques A, Krieger H, Camargo EP, da Silva LH. Hypoendemic malaria in Rondonia (Brazil, western Amazon region): seasonal variation and risk groups in an urban locality. Am J Trop Med Hyg. 1996 Jul; 55(1):32-8.

Cardoso MA, Ferreira MU, Ribeiro GS, Penteado MD, Andrade Junior HF. Dietary iron supplementation does not aggravate experimental malaria in young rats. J Nutr. 1996 Feb; 126(2):467-75.

Casals-Pascual C, Kai O, Cheung JO, Williams S, Lowe B, Nyanoti M, Williams TN, Maitland K, Molyneux M, Newton CR, Peshu N, Watt SM, Roberts DJ. Suppression of erythropoiesis in malarial anemia is associated with hemozoin in vitro and in vivo. Blood. 2006 Oct 15; 108(8):2569-77.

Cesta MF. Normal structure, function, and histology of the spleen. Toxicol Pathol. 2006; 34(5):455-65.

Cheng J, Baumhueter S, Cacalano G, Carver-Moore K, Thibodeaux H, Thomas R, Broxmeyer HE, Cooper S, Hague N, Moore M, Lasky LA. Hematopoietic defects in mice lacking the sialomucin CD34. Blood. 1996 Jan 15; 87(2):479-90.

Clark DJ. Guide for the care and use laboratory animals. Institute of Laboratory Animal Resources Commission on Life Sciences. National Research Council. Washington, DC. National Academy Press. 1996. 
Combes V, Coltel N, Faille D, Wassmer SC, Grau GE. Cerebral malaria: role of microparticles and platelets in alterations of the blood-brain barrier. Int $\mathrm{J}$ Parasitol. 2006 May 1; 36(5):541-6.

Cowman AF, Crabb BS. Invasion of Blood Cells by Malaria Parasite. Cell. 2006; 124(4):755-66.

Demar M, Legrand E, Hommel D, Esterre P, Carme B. Plasmodium falciparum malaria in splenectomized patients: two case reports in French Guiana and a literature review. Am J Trop Med Hyg. 2004 Sep; 71(3):290-3.

Dhermy D, Schrevel J, Lecomte MC. Spectrin-based skeleton in red blood cells and malaria. Curr Opin Hematol. 2007 May; 14(3):198-202.

Dor FJ, Ramirez ML, Parmar K, Altman EL, Huang CA, Down JD, Cooper DK. Primitive hematopoietic cell populations reside in the spleen: Studies in the pig, baboon, and human. Exp Hematol. 2006 Nov; 34(11):1573-82.

Drayton DL, Liao S, Mounzer $\mathrm{RH}$, Ruddle $\mathrm{NH}$. Lymphoid organ development: from ontogeny to neogenesis. Nat immunol. 2006; 7(4):344-353.

Eling WM. Role of spleen in morbidity and mortality of Plasmodium berghei infection in mice. Infect Immun. 1980 Dec; 30(3):635-41.

Engwerda CR, Beattie L, Amante $\mathrm{FH}$. The importance of the spleen in malaria. Parasitology. 2005; 21(2):75-80.

Faculdade de Medicina da Universidade Federal do Rio de Janeiro. Centro de informação em saúde para viajantes, Malária [homepage on the Internet]. Disponível em: http://www.cives.ufrj.br/informacao/malaria/mal-iv.html [2007 Jul 09].

Faucher JF, Creantor C, Hustache-Mathieu L, Chirouze C, Millon L, Hoen B. Atypical course of falciparum malaria in an asplenic patient. Presse Med. 2006 May; 35(5 Pt $1): 793-5$.

Favila-Castillo L, Monroy-Ostria A, Kobayashi E, Hirunpetcharat C, Kamada N, Good MF. Protection of rats against malaria by a transplanted immune spleen. Parasite Immunol. 1996 Jul; 18(7):325-31. 
Fell $\mathrm{AH}$, Smith NC. Immunity to asexual blood stages of Plasmodium: is resistance to acute malaria adaptive or innate? Parasitol Today. 1998 Sep; 14(9):364-9.

Garnica MR, de Moraes LV, Rizzo LV, de Andrade HF Jr. Supplementation of CXCL12 (CXCL12) induces homing of CD11C+ dendritic cells to the spleen and enhances control of Plasmodium berghei malaria in BALB/c mice. Immunology. 2005 Jul; 115(3):399-406.

Garnica MR, Silva JS, de Andrade Junior HF. Stromal cell-derived factor-1 production by spleen cells is affected by nitric oxide in protective immunity against blood-stage Plasmodium chabaudi CR in C57BL/6j mice. Immunol Lett. 2003 Oct 31; 89(2-3):133-42.

Garnica MR, Souto JT, Silva JS, de Andrade HF Jr. Stromal cell derived factor 1 synthesis by spleen cells in rodent malaria, and the effects of in vivo supplementation of SDF-1alpha and CXCR4 receptor blocker. Immunol Lett. 2002 Aug 1; 83(1):47-53.

Goodell MA, Rosenzweig M, Kim H, Marks DF, DeMaria M, Paradis G, Grupp SA, Sieff CA, Mulligan RC, Johnson RP. Dye efflux studies suggest that hematopoietic stem cells expressing low or undetectable levels of CD34 antigen exist in multiple species. Nat Med. 1997 Dec; 3(12):1337-45.

Gratama JW, Orfao A, Barnett D, Brando B, Huber A, Janossy G, Johnsen HE, Keeney M, Marti GE, Preijers F, Rothe G, Serke S, Sutherland DR, Van der Schoot CE, Schmitz G, Papa S. Flow cytometric enumeration of CD34+ hematopoietic stem and progenitor cells. European Working Group on Clinical Cell Analysis. Cytometry. 1998 Jun 15; 34(3):128-42.

Greenwood BM, Bojang K, Whitty CJ, Targett GA. Malaria. Lancet. 2005 Apr 23-29; 365(9469):1487-98.

Groom AC, Schmidt EE, MacDonald IC. Microcirculatory Pathways and Blood Flow in Spleen: New Insights From Washout Kinetics, Corrosion Casts, and Quantitative Intravital Videomicroscopy. Scan Micros. 1991; 5(1):159-174.

Hernandez-Valladares M, Naessens J, Musoke AJ, Sekikawa K, Rihet P, Ole-Moiyoi OK, Busher P, Iraqi FA. Pathology of Tnf-deficient mice infected with Plasmodium chabaudi adami 408XZ. Exp Parasitol. 2006 Dec; 114(4):271-8. 
Hristov M, Weber C. Endothelial progenitor cells: characterization, pathophysiology, and possible clinical relevance. J Cell Mol Med. 2004 Oct-Dec; 8(4):498-508.

Hunt NH, Grau GE. Cytokines: accelerators and brakes in the pathogenesis of cerebral malaria. Trends Immunol. 2003 Sep; 24(9):491-9.

Ing R, Segura M, Thawani N, Tam M, Stevenson MM. Interaction of Mouse Dendritic Cells and Malaria-Infected Erytrocytes: Uptake, Maturation, and Antigen Presentation. The $\mathrm{J}$ of Immunol. 2006; 176(1):441-450.

Janeway Jr. CA, Travers $\mathrm{P}$, Walport M, Shlomchik MJ. Immunobiology: the immune system in health and disease. $6^{\text {th }}$ ed. Jordan Hill, Oxford: Garland Science. 2005.

Jewett TJ, Sibley LD. Aldolase forms a bridge between cell surface adhesins and the actin cytoskeleton in apicomplexan parasites. Mol Cell. 2003 Apr; 11(4):885-94.

Jootar S, Chaisiripoomkere W, Pholvicha P, Leelasiri A, Prayoonwiwat W, Mongkonsvitragoon W, Srichaikul T. Suppression of erythroid progenitor cells during malarial infection in Thai adults caused by serum inhibitor. Clin Lab Haematol. 1993; 15(2):87-92.

Kiel MJ, Yilmaz OH, Iwashita T, Yilmaz OH, Terhorst C, Morrison SJ. SLAM family receptors distinguish hematopoietic stem and progenitor cells and reveal endothelial niches for stem cells. Cell. 2005 Jul 1; 121(7):1109-21.

Killick-Kendrick R. Parasitic protozoa of the blood of rodents: a revision of Plasmodium berghei. Parasitology. 1974 Oct; 69(2):225-37.

Killick-Kendrick $\mathrm{R}$, Warren $\mathrm{M}$. Primary exoerythrocytic schizonts of a mammalian Plasmodium as a source of gametocytes. Nature. 1968 Oct 12; 220(5163):191-2.

Kobari L, Giarratana MC, Gluckman JC, Douay L, Rosenzwajg M. Ex vivo expansion does not alter the capacity of umbilical cord blood CD34+ cells to generate functional T lymphocytes and dendritic cells. Stem Cells. 2006 Sep; 24(9):2150-7.

Kopp HG, Avecilla ST, Hooper AT, Rafii S. The bone marrow vascular niche: home of HSC differentiation and mobilization. Physiology (Bethesda). 2005 Oct; 20:349-56. 
Krause DS, Fackler MJ, Civin Cl, May WS. CD34: structure, biology, and clinical utility. Blood. 1996 Jan 1; 87(1):1-13.

Krücken J, Mehnert LI, Dkhil MA, El-Khadragy M, Benten WPM, Mossmann H, Wunderlich F. Massive destruction of Malaria-Parasited Red Blood Cells despite Spleen Closure. Infect and Immun. 2005; 73(10): 6390-6398.

Landau I, Killick-Kendrick R. Rodent plasmodia of the Republique Centrafricaine: the sporogony and tissue stages of Plasmodium chabaudi and P. berghei yoelii. Trans $R$ Soc Trop Med Hyg. 1966; 60(5):633-49.

Landau I, Miltgen F, Baccam D, Petit G, Roussillon C. Studies on Plasmodium atheruri. Ann Parasitol Hum Comp. 1983; 58(6):523-38.

Langhorne J, Albano FR, Hensmann M, Sanni L, Cadman E, Voisine C, Sponaas AM. Dendritic cells, pro-inflammatory responses, and antigen presentation in a rodent malaria infection. Immunol Rev. 2004 Oct; 201:35-47.

Leisewitz AL, Rockett KA, Gumede B, Jones M, Urban B, Kwiatkowski DP. Response of the splenic dendritic cell population to malaria infection. Infect Immun. 2004 Jul; 72(7):4233-9.

Li Z, Li L. Understanding hematopoietic stem-cell microenvironments. Trends Biochem Sci. 2006 Oct; 31(10):589-95.

Long GH, Chan BH, Allen JE, Read AF, Graham AL. Parasite genetic diversity does not influence TNF-mediated effects on the virulence of primary rodent malaria infections. Parasitology. 2006 Dec; 133(Pt 6):673-84.

Lorimore SA, Coates PJ, Scobie GE, Milne G, Wright EG. Inflammatory-type responses after exposure to ionizing radiation in vivo: a mechanism for radiationinduced bystander effects? Oncogene. 2001 Oct 25; 20(48):7085-95.

Lou J, Lucas R, Grau GE. Pathogenesis of cerebral malaria: recent experimental data and possible applications for humans. Clin Microbiol Rev. 2001 Oct; 14(4):81020.

Marsh K, Kinyanjui S. Immune effector mechanisms in malaria. Parasite Immunol. 2006 Jan-Feb; 28(1-2):51-60. 
Martin F, Kearney JF. Marginal-zone B cells. Nat Rev Immunol. 2002 May; 2(5):32335.

McDevitt MA, Xie J, Shanmugasundaram G, Griffith J, Liu A, McDonald C, Thuma P, Gordeuk VR, Metz CN, Mitchell R, Keefer J, David J, Leng L, Bucala R. A critical role for the host mediator macrophage migration inhibitory factor in the pathogenesis of malarial anemia. J Exp Med. 2006 May 15; 203(5):1185-96.

Ministério da Saúde. Portal da Saúde. [homepage on the Internet]. Disponível em: http://portal.saude.gov.br/portal/arquivos/pdf/be_malaria_01_2005.pdf [2007 Jul 09].

Mohan K, Stevenson MM. Dyserythropoiesis and severe anaemia associated with malaria correlate with deficient interleukin-12 production. Br J Haematol. $1998 \mathrm{Dec}$; 103(4):942-9.

Mueller I, Zimmerman PA, Reeder JC. Plasmodium malariae and Plasmodium ovale - the 'bashful' malaria parasites. Trends Parasitol. 2007 Jun; 23(6):278-83.

Nakamura $\mathrm{Y}$, Komano $\mathrm{H}$, Nakauchi $\mathrm{H}$. Two alternative forms of cDNA encoding CD34. Exp Hematol. 1993 Feb; 21(2):236-42.

Nakayama T, Mutsuga N, Tosato G. Effect of fibroblast growth factor 2 on stromal cell-derived factor 1 production by bone marrow stromal cells and hematopoiesis. J Natl Cancer Inst. 2007 Feb 7; 99(3):223-35.

Nitcheu J, Bonduelle O, Combadiere C, Tefit M, Seilhean D, Mazier D, Combadiere

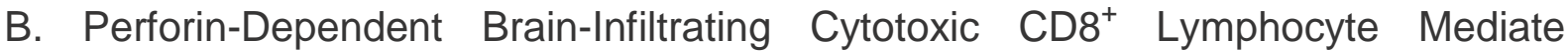
Experimental Cerebral Malaria Pathogenesis. J Immunol. 2003; 170:2221-2228.

Odeh $\mathrm{M}$. The role of tumour necrosis factor-alpha in the pathogenesis of complicated falciparum malaria. Cytokine. 2001 Apr 7; 14(1):11-8.

Osawa M, Hanada K, Hamada H, Nakauchi H. Long-term lymphohematopoietic reconstitution by a single CD34-low/negative hematopoietic stem cell. Science. 1996 Jul 12; 273(5272):242-5.

Oster CN, Koontz LC, Wyler DJ. Malaria in asplenic mice: effects of splenectomy, congenital asplenia, and splenic reconstitution on the course of infection. Am J Trop Med Hyg. 1980 Nov; 29(6):1138-42. 
Pamplona A, Ferreira A, Balla J, Jeney V, Balla G, Epiphanio S, Chora A, Rodrigues CD, Gregoire IP, Cunha-Rodrigues M, Portugal S, Soares MP, Mota MM. Heme oxygenase-1 and carbon monoxide suppress the pathogenesis of experimental cerebral malaria. Nat Med. 2007 Jun; 13(6):703-10.

Perkins SL, Sarkar IN, Carter R. The phylogeny of rodent malaria parasites: simultaneous analysis across three genomes. Infect Genet Evol. 2007 Jan; 7(1):7483.

Petithory JC, Khelil A, Galeazzi G, Ardoin F. Malaria in splenectomized patients. Three fatal cases. Presse Med. 2005 Apr 9; 34(7):519-21.

Pillai S, Cariappa A, Moran ST. Marginal zone B cells. Annu. Rev Immunol. 2005; 23:161-96.

Pusztaszeri MP, Seelentag W, Bosman FT. Immunohistochemical expression of endothelial markers CD31, CD34, von Willebrand factor, and Fli-1 in normal human tissues. J Histochem Cytochem. 2006 Apr; 54(4):385-95.

Satpathy SK, Mohanty N, Nanda P, Samal G. Severe falciparum malaria. Indian J Pediatr. 2004 Feb; 71(2):133-5.

Scerbaviciene R, Pilipavicius R. Malaria among seamen in Klaipeda during 19731998. Int Marit Health. 1999; 50(1-4):7-13.

Schmidt EE, MacDonald IC, Groom AC. Comparative Aspects of Splenic Microcirculatory Pathways in Mammals: The Region Bordering The White Pulp. Scan Micros. 1993; 7(2):613-628.

Shear HL, Nussenzweig RS, Bianco C. Immune phagocytosis in murine malaria. J Exp Med. 1979 Jun 1; 149(6):1288-98.

Smith NC, Favila-Castillo L, Monroy-Ostria A, Hirunpetcharat C, Good MF. The spleen, IgG antibody subsets and immunity to Plasmodium berghei in rats. Immunol Cell Biol. 1997 Jun; 75(3):318-23.

Sponaas AM, Cadman ET, Voisine C, Harrison V, Boonstra A, O'Garra A, Langhorne $\mathrm{J}$. Malaria infection changes the ability of splenic dendritic cell populations to stimulate antigen-specific T cells. J Exp Med. 2006 Jun 12; 203(6):1427-33. 
Stevenson MM, Riley EM. Innate immunity to malaria. Nat Rev Immunol. 2004 Mar; $4(3): 169-80$.

Stevenson MM, Urban BC. Antigen presentation and dendritic cell biology in malaria. Parasite Immunol. 2006 Jan-Feb; 28(1-2):5-14.

Stoltenburg-Didinger G, Neifer S, Bienzle U, Eling WM, Kremsner PG. Selective damage of hippocampal neurons in murine cerebral malaria prevented by pentoxifylline. J Neurol Sci. 1993 Jan; 114(1):20-4.

Suda J, Sudo T, Ito M, Ohno N, Yamaguchi Y, Suda T. Two types of murine CD34 mRNA generated by alternative splicing. Blood. 1992 May 1; 79(9):2288-95.

Sultan AA, Thathy V, Frevert U, Robson KJ, Crisanti A, Nussenzweig V, Nussenzweig RS, Menard R. TRAP is necessary for gliding motility and infectivity of plasmodium sporozoites. Cell. 1997 Aug 8; 90(3):511-22.

Superintendência de controle de endemias. Malária - básico e informações para profissionais da saúde [homepage on the Internet]. Disponível em: http://www.sucen.sp.gov.br/doencas/malaria/texto_malaria_pro.htm\#invest [2007 Jul $11]$.

Suzuki M, Waki S, Igarashi I, Takagi T, Miyagami T, Nakazawa S. An alternative approach to malaria vaccine with a permanent attenuated mutant from a high virulence Plasmodium berghei strain. Zentralbl Bakteriol Mikrobiol Hyg [A]. 1987 May; 264(3-4):319-25.

Tajima F, Sato T, Laver JH, Ogawa M. CD34 expression by murine hematopoietic stem cells mobilized by granulocyte colony-stimulating factor. Blood. 2000 Sep 1; 96(5):1989-93.

Taylor LH, Walliker D, Read AF. Mixed-genotype infections of malaria parasites: within-host dynamics and transmission success of competing clones. Proc Biol Sci. 1997 Jun 22; 264(1383):927-35.

Taylor TE, Strickland GT. Infections of the Blood and Reticuloendothelial System. In: Strickland GT. Hunter's Tropical Medicine an Emerging Infectious Diseases. $8^{\text {th }}$ ed. Baltimore: W.B. Saunders Company. 2000; p. 614-643. 
Uneke CJ. Congenital Plasmodium falciparum malaria in sub-Saharan Africa: a rarity or frequent occurrence? Parasitol Res. 2007 Jun 5.

Urban BC, Hien TT, Day NP, Phu NH, Roberts R, Pongponratn E, Jones M, Mai NT, Bethell D, Turner GD, Ferguson D, White NJ, Roberts DJ. Fatal Plasmodium falciparum malaria causes specific patterns of splenic architectural disorganization. Infect Immun. 2005 Apr; 73(4):1986-94.

Villeval JL, Lew A, Metcalf $\mathrm{D}$. Changes in hemopoietic and regulator levels in mice during fatal or nonfatal malarial infections. I. Erythropoietic populations. Exp Parasitol. 1990 Nov; 71(4):364-74.

Vinckei IH, Lips M. Cyclic transmission of Plasmodium berghei. Ann Soc Belg Med Trop. 1950 Dec 31; 30(6):1605-11.

Weiss L, Geduldig U, Weidanz W. Mechanisms of splenic control of murine malaria: reticular cell activation and the development of a blood-spleen barrier. Am J Anat. $1986 \mathrm{Jul} ;$ 176(3):251-85.

Weiss L. Mechanisms of splenic control of murine malaria: cellular reactions of the spleen in lethal (strain 17XL) Plasmodium yoelii malaria in BALB/c mice, and the consequences of pre-infective splenectomy. Am J Trop Med Hyg. 1989 Aug; 41(2):144-60.

Weiss L. The spleen in malaria: the role of barrier cells. Immunol Lett. 1990 Aug; 25(1-3):165-72.

Wickramasinghe $\mathrm{SN}$, Abdalla $\mathrm{SH}$. Blood and bone marrow changes in malaria. Baillieres Best Pract Res Clin Haematol. 2000 Jun; 13(2):277-99.

Wheeler DL, Chappey C, Lash AE, Leipe DD, Madden TL, Schuler GD, Tatusova TA, Rapp BA. Database resources of the National Center for Biotechnology Information. Nucleic Acids Res. 2000 Jan 1; 28(1):10-4.

Winkler IG, Levesque JP. Mechanisms of hematopoietic stem cell mobilization: when innate immunity assails the cells that make blood and bone. Exp Hematol. 2006 Aug; 34(8):996-1009.

World health Organization. Health Topics, Malaria [homepage on the Internet]. Disponível em: http://www.who.int/topics/malaria/en/ [2007 Jul 11]. 
Yap GS, Stevenson MM. Production of soluble inhibitor of erythropoiesis during Plasmodium chabaudi AS infection in resistant and susceptible mice. Ann NY Acad Sci. 1991; 628:279-81.

Yin T, Li L. The stem cell niches in bone. J Clin Invest. 2006 May; 116(5):1195-201. 


\section{SUMÁRIO}

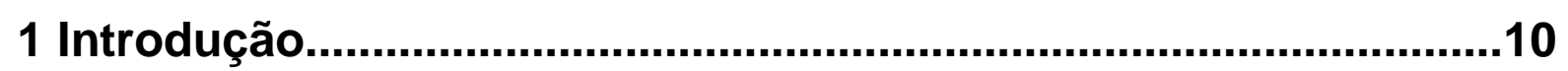

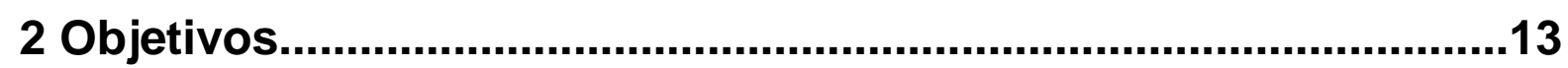

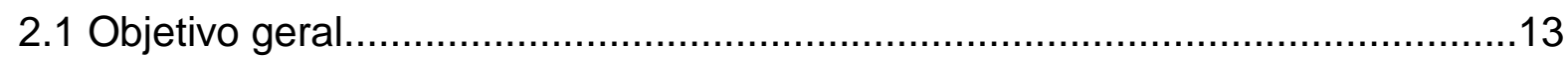

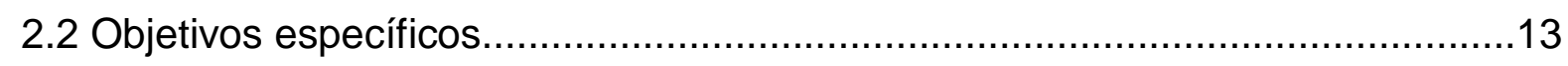

3 Revisão de Literatura...............................................................14

4 Material e Métodos.........................................................................34

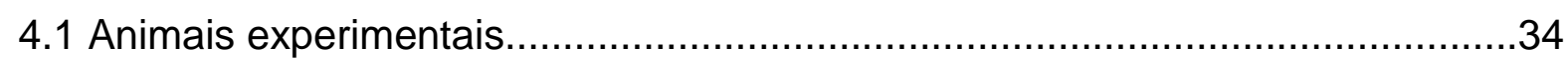

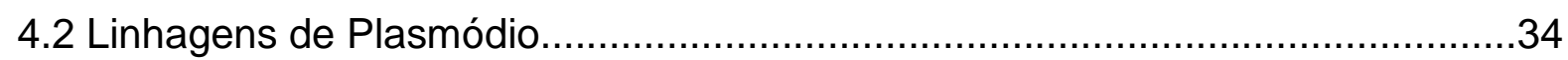

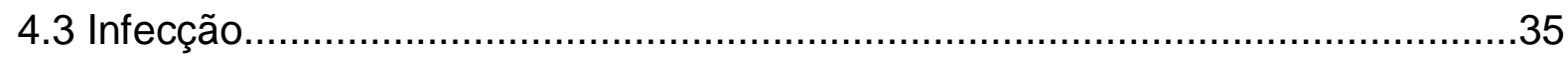

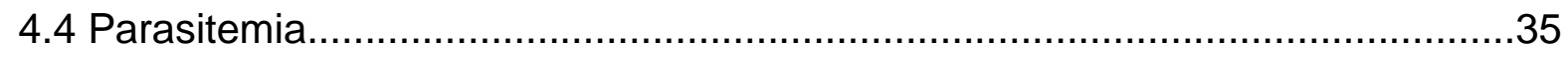

4.5 Sacrifício, remoção dos baços e determinação da sua massa.............................35

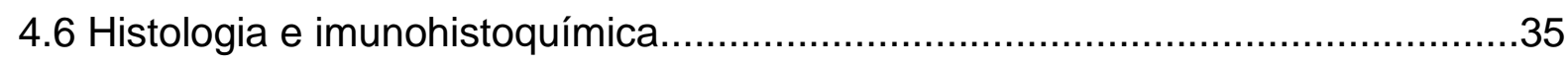

4.7 Morfometria da proporção de polpa branca e polpa vermelha no baço...............37

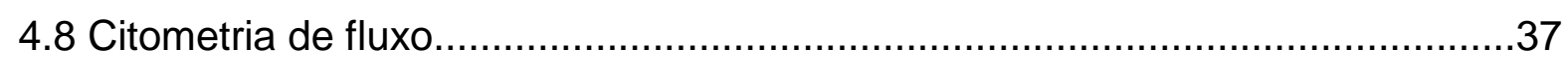

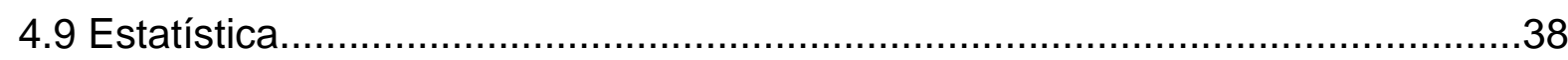

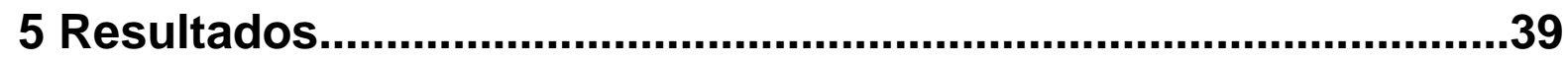

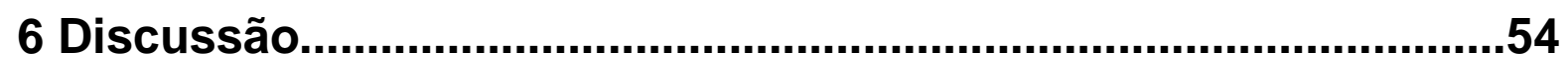

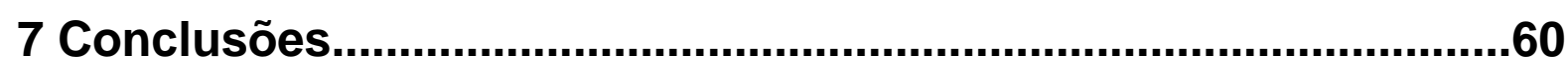

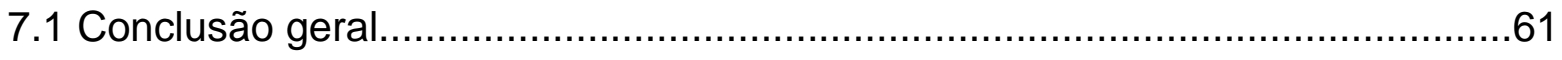

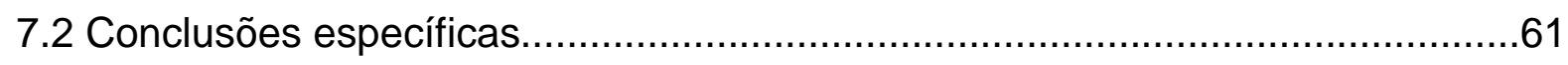

Referências Bibliográficas..........................................................64 